\title{
Specialization and Exports in South America after Trade Agreements
}

\author{
Valentina Viego \\ Universidad Nacional del Sur \& Instituto de Investigaciones Económicas y Sociales del Sur, Babia Blanca, Argentina \\ Virginia Corbella \\ Universidad Nacional del Sur, Bahía Blanca, Argentina
}

\begin{abstract}
A vast body of literature recognizes that economic integration brings asymmetric benefits for the actors carrying out the process. Regional integration agreements influence the level of industrial activity and its location, preventing some countries from fully participating as beneficiaries. This study aims to examine the changes in production and export structures of South American manufacturing sector after the signing of trade agreements. We performed unit root tests with endogenous breaks, cointegration tests, and stochastic frontier models on production and export for the period 1985 2008. Our results show that after the signing of trade agreements, changes in the structure of production and export have been weak, and thus trade agreements have not boosted structural changes in specialization and export intensity in South American countries.
\end{abstract}

JEL Classifications: F13, F15

Keywords: Regional Integration, Specialization, Manufacturing Exports, Trade Agreements, South America

\footnotetext{
* Corresponding Author: Valentina Viego; Economics Department, Universidad Nacional del Sur, San Andres 800, Campus Univeristario Palihue, 8000 Bahía Blanca, Argentina, Tel+542914595138, Fax +542914595139, Email: vviego@criba.edu.ar

Co-author: Virginia Corbella; Economics Department, Universidad Nacional del Sur, San Andres 800, Campus Univeristario Palihue, 8000 Bahía Blanca, Argentina, Tel +542914595138, Fax +542914595139, Email: corbellavirginia@hotmail.com
} 


\section{Introduction}

According to a vast body of literature on international trade, economic integration brings asymmetric benefits between the actors who carry out that process (Bouzas 2003, Venables 2003, among others). The creation of Regional Trade Agreements (RTAs) has impacts on the behavior of industrial activities, creating impediments for some countries to sufficiently gain as beneficiaries of that integration process. Some authors argue that asymmetries in economic structure affect the capacity of appropriation of benefits, which may set up an obstacle to further integration (Lo Turco 2007, Terra 2008, Venables 1999, 2003a, and 2003b, Imbs et al. 2012, Bouzas 2003, Bouzas and Da Motta Veiga 2008).

In the context of symmetric and asymmetric RTAs, Venables (2003a) analyzes the impact on the production and location of activities in member countries. This author poses that in South-South RTAs, the demand relations become more relevant, since intraregional demand becomes the engine of industrialization in those countries. Puga and Venables (1999) also found a slow process of industrialization emerging from such agreements. The central hypothesis of that approach is that a customs union formed by countries that share similar comparative advantages would benefit those with intermediate comparative advantages among its trading partners and the rest of the world, but at the expense of those members who have extreme comparative advantages or are highly specialized in a few sectors. Therefore, the presence of preferential tariffs or commitments undertaken in RTAs may affect local production, and strengthen the role of regional comparative advantages in shaping production patterns.

While the vast majority of South American countries have signed numerous trade agreements during the last three decades, those initiatives have not been exempt from conflicts whenever free intraregional trade was perceived as a threat by local businesses. As a result, bargains attained advancements, went backwards, and stopped (Porta 2008), leading to a modest effective decrease in intra-regional trade barriers (Rodriguez Mendoza 2012). Thus, compared with other regional blocks, such as the European Union or the Association of Southeast Asian Nations (ASEAN), the degree of regional integration in South America is lower. However, exports have served as a countercyclical force in regional economies (Baumann 2008, Estevadeordal 2012).

In South America, intra-regional trade has increased since the 1990s (Gayá and Michalczewsky 2014, Estevadeordal, 2012). According to World Integrated Trade 
Solution (WITS 2011) ${ }^{1}$, intra-regional commerce represents about 19 percent of total exports from the region. However, trade intensity is quite different when considering manufacturing figures. Although approximately 52 percent of South American total exports are manufactured, 38 percent of it is based on raw materials, which significantly alters the size of pure manufacturing on regional export profile. That proportion increases in intra-regional grounds, where 73 percent of total exports within the region are manufactured, but 20 percent are linked to the primary sector.

The objective of this study is to econometrically test the contemporaneity of changes between the signing in RTAs and manufacturing specialization in South America. In particular, we aim to check if the potential advantages of each country in a sector have been effectively exploited, and, if so, if it occurred as a consequence of trade agreements.

Based on unit root tests that include endogenous breaks, we first analyze if the series of specialization and revealed comparative advantage faced breaks in their trajectory, and whether shocks were contemporary to the signing of trade agreements. Second, we test cointegration between specialization and effective exports. Finally, in order to assess whether the specialization in the four manufacturing sectors has resulted in revealed advantages, we use a stochastic frontier model, which provides the degree of utilization (inefficiency) of those advantages.

\section{Data and Materials}

We analyze the relationship between trade agreements, location, and export pattern changes in manufacturing. However, agricultural production cannot react in the same way to RTAs, since location and production decisions are tied to land. The relative ubiquity of manufacturing makes them sensitive to integration processes.

Second, we explore the consequences of trade agreements on specialization and exports in a sample of ten South American countries (i.e., Argentina, Bolivia, Brazil, Chile, Colombia, Ecuador, Paraguay, Peru, Uruguay, and Venezuela) ${ }^{2}$. In South

\footnotetext{
${ }^{1}$ WITS is an online platform database developed jointly by the World Bank, the United Nations Conference on Trade and Development (UNCTAD), United Nations Statistical Division (UNSD) and the World Trade Organization (WTO).

${ }^{2}$ We exclude Suriname and Guyana from the analysis as their available series are relatively short and the techniques used have asymptotic properties, a condition that can diminish power to conclusions.
} 
America, trade and RTAs began in the late 1960s with the signing of the Andean Community between Bolivia, Chile, Colombia, Ecuador, and Peru. The last trade agreement occurred in 2014 between Brazil and Venezuela. RTAs were at their height during the 1990s when other structural reforms involving macroeconomic management, government financing, public enterprises, and openness were underway.

In order to capture specialization, we compute the location quotient proposed by Hoover (1936). The index is considered as location and specialization indicator of a given country/region in a certain sector. The index is computed as:

$$
\text { Specialization index }(I E)_{j}=\frac{\frac{V A_{i j}}{\sum_{i} V A_{i j}}}{\frac{\sum_{j} V A_{i j}}{\sum_{i} \sum_{j} V A_{i j}}}
$$

where $V A_{i j}$ denotes value added in sector $i$ in country $j$.

If the ratio is greater than unity, the country in question specializes in the production of goods offered by sector $i$; therefore, that sector has greater export potential in that country to the rest of the region. If $I E_{j}<1$, the country $j$ is not specialized in this sector and is likely to be a net importer of products of the sector. When $I E_{j}$ equals the unit, there is no clear pattern of specialization in the sector. The source for the added value has been the PADI database of CEPAL, which is supplemented, in some cases, by data from official statistics addresses of each of the member countries.

Effective exports are measured by the revealed comparative advantage index $V C R$ proposed by Balassa $(1965)^{3}$. Further, this indicator has been modified so that it becomes an index of regional comparative advantage. Our index reports the involvement of $k^{\prime} \mathrm{s}$ exports from the $i$-th country with respect to the participation of that sector in regional exports. This indicates the relative position of each country of the block in each of the industrial sectors within the region.

$V C R$ index is performed according to the following formula:

${ }^{3}$ This is also a variant from Hoover's location quotient. 


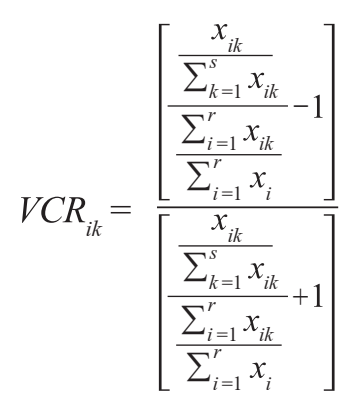

The ratio $\frac{\frac{x_{i k}}{\sum_{k=1}^{s} x_{i k}}}{\frac{\sum_{i=1}^{r} x_{i k}}{\sum_{i=1}^{r} x_{i}}}$ represents the proportion of exports of the $k$-th sector in the $i$-th country of total exports to South America. While the relationship $\frac{\sum_{i=1}^{r} x_{i k}}{\sum_{i=1}^{r} x_{i}}$ exhibits the proportion of exports of sector $k$ of total exports of all countries to region. In order to be symmetrical, the index is standardized, so the values are within a range of -1 and 1. Positive index values suggest a revealed comparative advantage in the specific sector, whereas negative values indicate a disadvantage. A null value would exhibit an indifference situation.

We employ data from the manufacturing sector (value added and exports) classified according to the international classification system ISIC $^{4}$, Revision 2 . They have been classified into four categories, according to their technological content: manufactured products based on high, medium, low technology, and natural resources-based activities. The classification is based on Lall $(1998,2000)$ and Lall and Mengistae (2005). The figures for intra- and extra-industry trade flows were obtained from the base of UNComtrade data. All information has been processed and harmonized within the system of international classification ISIC, Revision 2.

\section{Unit Root Tests}

Due to reductions in tariffs and mobility of goods and production factors, different

${ }^{4}$ International Standard Industrial Classification 
approaches agree that the integration processes may cause changes in the geographical distribution of production and trade specialization of the members signing the agreement (Imbs et al. 2012). The approaches differ in terms of the direction of the locational changes: a theoretical line poses that trade integration promotes agglomeration (Krugman and Venables 1996), another one asserts that trade agreements stimulates locational dispersion (Forslid and Wooton 2003), and a third one recognizes forces that can simultaneously act in opposite directions (Puga 1999). These changes may generate costs and benefits difficult to predict in terms of their distribution between countries or between the geographical regions involved.

In addition, locational and production changes that arise as a consequence of trade agreements between countries usually occur gradually and with a time delay, as they involve long-term decisions (Puga 1999, Venables 2003a). Therefore, the variations in the patterns of specialization and/or trade patterns between countries cannot be observed until a certain extent of time passes after the agreement.

One way to empirically check the occurrence of such changes is by testing the presence of breaks in the series of specialization and revealed regional advantages. The method selected is the unit root test proposed by Zivot and Andrews (1992), henceforth, ZA. Unlike other classical unit root tests, the ZA test can identify breaks endogenously, which prevents an ad hoc date choice. Therefore, this mechanism allows us to identify whether a structural change on a series could be related to a given policy and/or specific event. $^{5}$

ZA tests the null hypothesis that the series has a unit root with no breaks, which implies that $\alpha=0$ against the alternative that $\alpha<1$. In this context, rejecting the null implies that the series follows a stationary process with a break. In turn, the break is located at the time period for which the Augmented Dickey Fuller (known as ADF) test statistic is at a minimum, and usually assumes a negative value. Consequently, the break date is selected when the evidence is less favorable to the null. If rejected, the series would remain stationary but exhibit a break in period $\mathrm{t}$ - in the intercept, the trend, or both-depending on the selected specification. We examined the three specifications in order to assess the robustness of the findings.

Table 1 shows the main results obtained from the ZA test as applied to each series and specification. Test statistics and critical values are exhibited in Table A1 in the

\footnotetext{
5 Lumsdaine and Papell (1997), Perron (1997), and Ohara (1999), among others, developed other variants of unit root tests with endogenous breaks. The choice of test applied in this case was based on the availability of the calculation routine used in the econometric software (Stata).
} 
Appendix.

The ZA test shows evidence of breaks in some series, especially $V C R$. In the $I E$ series, Paraguay and Ecuador have few observations; therefore, they have not been taken into account to avoid affecting the robustness of results. The test leads to consistent results under any specification, except for some cases in which specifications identify different dates for breaks for the same series (e.g., Argentina and Brazil in the midtechnology sector, Peru in high and natural resources-based technology, and Bolivia in natural resources-based sectors). This may be because the series probably has experienced breaks in both years, but, by construction, ZA supports only one break ${ }^{6}$. Therefore, in cases where the null is rejected, while breaks are distantly located from signing agreements, the analysis was complemented with charts of each series by sector and country.

On the other hand, trade agreements are considered contemporary with structural breaks in the series if the identified break matches, or if it occurred two and three years from the signing of the agreement (Gonzalez and Delbianco 2011).

Table 1. Unit root tests and endogenous breaks in specialization and export pattern

\begin{tabular}{|c|c|c|}
\hline & Specialization Index (IE) & $\begin{array}{l}\text { Revealed Comparative } \\
\text { Advantage }(V C R)\end{array}$ \\
\hline \multicolumn{3}{|l|}{ Argentina } \\
\hline High technology & & $\begin{array}{l}\text { Break in 2002, possibly related } \\
\text { with agreement in } 2000\end{array}$ \\
\hline Mid technology & $\begin{array}{l}\text { Break in 2001possibly related } \\
\text { with agreement in } 2000\end{array}$ & $\begin{array}{l}\text { Break in 1991, possibly related } \\
\text { with agreement in the same year }\end{array}$ \\
\hline Low technology & & $\begin{array}{l}\text { Break in } 2002 / 2004 \text {, possibly related } \\
\text { with agreements in } 2000 \text { to } 2004\end{array}$ \\
\hline \multicolumn{3}{|l|}{ Bolivia } \\
\hline High technology & Break in 1988/1989 & $\begin{array}{c}\text { Break in 1998/2002, possibly related } \\
\text { with agreements in } 1996 \text { and } 2000\end{array}$ \\
\hline Mid technology & $\begin{array}{l}\text { Not related with contemporary } \\
\text { trade agreements }\end{array}$ & \\
\hline Low technology & $\begin{array}{l}\text { Break in 1993, possibly related } \\
\text { with agreement in the same year }\end{array}$ & \\
\hline $\begin{array}{l}\text { Natural resources } \\
\text { based technology }\end{array}$ & $\begin{array}{l}\text { Break in 1995, possibly related } \\
\text { with agreement in } 1993\end{array}$ & $\begin{array}{l}\text { Break in } 2000 \text {, possibly related with } \\
\text { agreement in the same year }\end{array}$ \\
\hline
\end{tabular}

\footnotetext{
${ }^{6}$ In fact, there are unit root tests that allow for two breaks, like Clemente et al. (1998). They were not applied here due to their asymptotic properties and insufficient temporal coverage of available data.
} 
(continued)

\begin{tabular}{|c|c|c|}
\hline & Specialization Index (IE) & $\begin{array}{l}\text { Revealed Comparative } \\
\text { Advantage }(V C R)\end{array}$ \\
\hline \multicolumn{3}{|l|}{ Brazil } \\
\hline High technology & & $\begin{array}{c}\text { Break in 2002, possibly related } \\
\text { with agreements occurred in } 2000 \\
\text { and } 2001\end{array}$ \\
\hline Mid technology & $\begin{array}{l}\text { Break in 1999, possibly related } \\
\text { with agreements in } 1996\end{array}$ & $\begin{array}{c}\text { Break in 1993/1994, possibly related } \\
\text { with agreements in } 1991\end{array}$ \\
\hline \multicolumn{3}{|l|}{ Chile } \\
\hline High technology & & $\begin{array}{c}\text { Break in 1994/1995, possibly related } \\
\text { with agreements in } 1993\end{array}$ \\
\hline Mid technology & $\begin{array}{l}\text { Break in 1996, possibly related } \\
\text { with agreements in the same year }\end{array}$ & \\
\hline $\begin{array}{l}\text { Natural resources } \\
\text { based technology }\end{array}$ & $\begin{array}{l}\text { Break in } 1989 / 1990 . \text { Not related with } \\
\text { Contemporary trade agreements }\end{array}$ & \\
\hline \multicolumn{3}{|l|}{ Colombia } \\
\hline Mid technology & & $\begin{array}{l}\text { Break in 1991. Not related with } \\
\text { contemporary trade agreements }\end{array}$ \\
\hline $\begin{array}{l}\text { Natural resources } \\
\text { based technology }\end{array}$ & & $\begin{array}{l}\text { Break in } 1993 . \text { Not related with } \\
\text { contemporary trade agreements }\end{array}$ \\
\hline \multicolumn{3}{|l|}{ Ecuador } \\
\hline High technology & & $\begin{array}{l}\text { Break in 1993. Not related with } \\
\text { Contemporary trade agreements }\end{array}$ \\
\hline Mid technology & & $\begin{array}{l}\text { Break in 1991. Not related with } \\
\text { contemporary trade agreements }\end{array}$ \\
\hline Low technology & & $\begin{array}{l}\text { Break in } 1989 . \text { Not related with } \\
\text { contemporary trade agreements }\end{array}$ \\
\hline \multicolumn{3}{|l|}{ Paraguay } \\
\hline High technology & & $\begin{array}{c}\text { Break in 1998/1999, possibly related } \\
\text { with agreements occurred in } 1996\end{array}$ \\
\hline Mid technology & & $\begin{array}{c}\text { Break in } 1999 / 2000 \text {, possibly related } \\
\text { with agreements occurred in } 2000\end{array}$ \\
\hline $\begin{array}{l}\text { Natural resources } \\
\text { based technology }\end{array}$ & & $\begin{array}{l}\text { Break in 1995. Not related with } \\
\text { contemporary trade agreements }\end{array}$ \\
\hline \multicolumn{3}{|l|}{ Peru } \\
\hline High technology & $\begin{array}{l}\text { Break in } 1995 / 1999 . \text { Not related with } \\
\text { contemporary trade agreements }\end{array}$ & $\begin{array}{c}\text { Break in } 1996 / 1998 . \text { Not related with } \\
\text { contemporary trade agreements }\end{array}$ \\
\hline Low technology & $\begin{array}{c}\text { Break in } 1999 / 2000 \text {, possibly related } \\
\text { with agreement in } 2000\end{array}$ & \\
\hline $\begin{array}{l}\text { Natural resources } \\
\text { based technology }\end{array}$ & $\begin{array}{c}\text { Break in } 1998 / 2000 \text {, possibly related } \\
\text { with agreement in } 2000\end{array}$ & $\begin{array}{l}\text { Break in 1989/1999. Not related with } \\
\text { contemporary trade agreements }\end{array}$ \\
\hline
\end{tabular}


(continued)

\begin{tabular}{|c|c|c|}
\hline & Specialization Index (IE) & $\begin{array}{l}\text { Revealed Comparative } \\
\text { Advantage (VCR) }\end{array}$ \\
\hline \multicolumn{3}{|l|}{ Uruguay } \\
\hline High technology & & $\begin{array}{c}\text { Break in 1994, possibly related } \\
\text { with agreement in } 1991\end{array}$ \\
\hline Mid technology & $\begin{array}{l}\text { Break in 1994, possibly related } \\
\text { with agreement in } 1991\end{array}$ & \\
\hline Low technology & $\begin{array}{c}\text { Break in } 1989, \text { possibly related } \\
\text { with agreement in } 1986\end{array}$ & $\begin{array}{c}\text { Break in } 1989 \text {, possibly related } \\
\text { with agreement in } 1986\end{array}$ \\
\hline $\begin{array}{l}\text { Natural resources } \\
\text { based technology }\end{array}$ & $\begin{array}{l}\text { Break in 1991, possibly related } \\
\text { with agreement in the same year }\end{array}$ & \\
\hline \multicolumn{3}{|l|}{ Venezuela } \\
\hline Low technology & $\begin{array}{l}\text { Break in } 1990 . \text { Not related with } \\
\text { contemporary trade agreements }\end{array}$ & \\
\hline $\begin{array}{l}\text { Natural resources } \\
\text { based technology }\end{array}$ & $\begin{array}{l}\text { Break in 1988/1989. Not related with } \\
\text { contemporary trade agreements }\end{array}$ & \\
\hline
\end{tabular}

In Argentina, the largest detected breakdowns occurred with revealed advantages series and focused in high, mid, and low-tech sectors. Additionally, mid-technology sector recorded a break in $I E$ in 2001. It is worth noting that the shock in $I E$ occurred after that, experienced by the same sector in $V C R$, which could lead to the conclusion that variation in exports pattern of mid-tech manufacturing goods did not emerge from significant changes in specialization. In turn, the high- and low-tech manufacturing sectors experienced substantial changes in $V C R$ without evidence of shocks in $I E$. Finally, Argentina recorded no evidence of significant breaks in the patterns of specialization or exports based on natural resource sector, a sector in which the country is specialized according to its specialization index.

In Bolivia, breaks occurred mainly in $I E$ series in the mid- and low-tech and natural resource-based manufacturing, where the latter two related with trade agreements signed by the country. In the $V C R$ series, breaks occurred in the high-tech sector and natural resource-based manufacturing, which could be possibly linked to trade agreements. Dates of breaks in $I E$ series are precedent to those identified in $V C R$ series, but, as they are associated with different sectors (they match only in the natural resources based sector), that suggest that changes in the country's exports in those sectors do not emerge from changes in specialization. Only in the manufacturing sector based on natural resources, in which Bolivia is specialized, the break in $I E$ series is precedent to the one 
faced by $V C R$. Therefore, these results might indicate that trade agreements have led to changes in the production of goods, which, in turn, lead to intensified exports to the rest of regional partners.

Brazil exhibits breaks in $V C R$ in two sectors: high- and mid-tech manufacturing. In the latter, in both series, the ZA indicates dates for breaks possibly associated with the signing of trade agreements. However, the breakdown dates differ; the process that generates $V C R$ series changed before the one underlying $I E$.

In the case of Chile, breaks are detected mostly in $I E$, especially in mid-tech and natural resource-based sectors. $I E$ series shows that Chile also recorded an increasing tendency to specialize in those sectors. Chile's VCR changed suddenly in 1994 1995. Furthermore, breaks do not coincide by sector, so there is no evidence of contemporaneity in the shocks experienced by both series. However, both in highand mid-tech breaks could be related with trade agreements. In other words, two of the three breaks identified by the ZA test may be possibly associated with regional trade agreements; although, as noted above, this could not be speculated with a sequence of the type: trade agreement $\rightarrow$ locational change/specialization $\rightarrow$ exports boost.

In Colombia, IE series exhibited no breaks, and series breaks were observed only in VCR in the two sectors (mid-tech and natural resources) the country is specialized in, but they cannot be associated with contemporaneous trade agreements. Therefore, it seems that those breaks do not constitute reactions in sectors in which the country was already facing competitive business alliances. In the low-tech sector, Colombia evolved from not specialized to specialized (as the index grew from $<1$ to $>1$ ), yet the test did not identify any break in both series for this sector.

In the case of Ecuador and Paraguay, $I E$ series have insufficient observations, so the results lack of robustness. Therefore, we only present results for $V C R$ series. In the case of Ecuador, the ZA test locates breaks not associated with contemporary trade agreements in the sectors of high-, mid- and low-technology. In these sectors, the country either exhibited a downward trend in specialization or no specialization at all. Dates identified by the ZA test correspond to significant decreasing in specialization index, or the least level of specialization in the case of mid-tech sector. In the case of Paraguay, the breakdowns in the revealed advantages series were found in the sectors of high- and mid-tech and natural resourced-based manufacturing, where the latter is the only sector in which the country is specialized in, and the break is hardly related with a trade agreement. In the other two sectors, the breaks could be associated with the signing of trade agreements by the country. 
In the case of Peru, breaks are detected in three of the four sectors considered: high- and low- technology sector and natural resource-based activities. In the last two sectors, the country reveals as specialized. In $I E$, series breaks were detected under three specifications in aforementioned sectors, while in $V C R$, just high-tech and natural resource-based activities show significant breaks. Furthermore, the breaks did not occur near or after the signing of trade agreements. The dates of breakdown identified by the test in the series of specialization are approximate to each other, and associated with the signing of trade agreements, except in the high-tech sector, where the break occurred before the trade agreement of 2000 .

Uruguay, like Bolivia, recorded breaks in the four sectors covered. In this case, breaks were identified in both series (mostly in $I E$ ). However, in different sectors, the breaks only match in the low-tech manufacturing sector where the ZA test located the break in the same date, which can also be associated to the signing of trade treaties.

Finally, Venezuela faced breaks in $I E$ series in low-tech sectors and natural resourcebased manufacturing, which could not be linked to trade deals, even though the dates selected by the test are close together.

In short, the evidence in favor of trade agreements followed by changes in industrial location and, in turn, variations in export pattern is mixed in South American economies. The most common situation is the presence of instability (unit root processes) in specialization and revealed advantage series. Breaks, when located, occurred after the signing of trade alliances, but concentrated mainly in exports and less in location/ specialization.

The only case where such sequence has some evidence is the low-tech sector in Uruguay.

Taking into account contemporary breaks with trade agreements by sector, $I E$ concentrated ruptures in mid-technology sectors, while VCR exhibits more breaks in the high-tech sector. Natural resource-based manufacturing exhibited a fewer number of breaks after the signing of regional trade acts.

As for the VCR series, a higher concentration of breaks in the periods 1990 2002 is observed, since the 1990s also saw a higher occurrence of RTAs. A total of 20 breaks were identified in that series, where 12 of them were associated with trade agreements. Meanwhile, IE series exhibit a total of 15 breaks in the years 1988, 1989, and 1999, and some individual years during the 1990s (depending upon the country). 10 of the 15 breaks were associated with RTAs.

The breaks are rarely presented in both series in the same sector. Most cases show 
a break in one series and sector, except in five cases (Argentina and Brazil in mid-tech sector, Bolivia in natural resourced-based sector, and Peru in high-tech and natural resource-based sectors). In the cases studied, only two dates follow the expected sequence, and the dates agree in just one case. Otherwise, the break in the $V C R$ series is prior to the one in $I E$ series, and the rest is difficult to determine, because the test identifies two different dates in each series as potential ruptures.

Although other exercises are required to test causality between breaks and the signing of trade agreements, the results indicate that specialization and revealed advantage figures are not stable, but cannot also be univocally associated with trade agreements. Additionally, when structural changes in their processes emerge, the evidence in favor of changes as a result of trade acts reactions is mixed. Breaks may have multiple origins, and do not reproduce a succession of locational change followed by variations in exports intensity.

\section{A Cointegration Approach}

As already mentioned, RTAs may entail changes in specialization and trade of the participating countries, but such changes may occur with a time delay. The index of specialization not only indicates whether a country is specialized in the production of a certain good but also provides information about the potentiality of becoming a net exporter of such goods to the rest of the countries. If that trade potential is exploited, it should be translated into concrete changes in the country's pattern of trade. Moreover, it could also trigger further changes in the production structure. In econometric terms, this would imply the existence of long-term relationships or cointegration between $I E$ and VCR.

To test the existence of a cointegration relationship between two variables, it is necessary to test if each independent series has a unit root or is stationary. In part, this task has been determined previously (based on the ZA tests). However, since it is possible to arrange the data in panel form, the presence of unit roots in series may exploit the information provided by a panel data structure. A set of different methods was chosen to test the existence of unit root in each series in the context of panel data. These methods include the Levin Lin Chu (2002) (or LLC) and Im-Pesaran Shin (2003) (or 
IPS), which are recognized in the literature as first generation unit root tests for panels. In turn, we've appraised some of the set of second generation unit root tests for panels such as the cross-sectionally augmented Dickey Fuller test developed by Pesaran (2003) (or CADF) and cross-sectionally augmented IPS proposed by Pesaran (2007) (or CIPS). A review of unit root tests for panel data is in Hurlin and Mignon (2007).

Unit root tests were applied in both $I E$ and $V C R$ series by country. In some cases, tests were carried out with seven countries - instead of 10 - in order to meet the information requirements of each test. The models used are based on a panel structure with two-dimensions: cross-section and time. However, the problem here contains three dimensions (country, period, and sector), so a variable sector/country was created to get just two dimensions. The resulting panel contains cross-section observations corresponding to a given sector in a given country each year.

The LLC test applied to the $I E$ series indicates that all panels are stationary. However, if the test is applied on a sample of seven countries, results indicate that all panels have a unit root. The IPS test concludes that the panels are stationary, if a trend is included; otherwise, they follow a unit root. In the case of test CADF, IE series has a unit root with different specifications selected. In turn, the CIPS test indicates that some panels are stationary in the sample with 10 countries, with the opposite conclusion (e.g., unit root) when 7 countries are considered.

For the $V C R$ series, tests results are more homogeneous. Upon the LLC test, all panels are stationary in both samples. A similar conclusion emerges performing the IPS test, CADF, and CIPS — some panels are stationary, so some might follow a unit root process.

In short, the evidence would indicate that the $V C R$ series is panel stable, while the evidence for IE series supports the existence of a unit root. As second generation tests indicate some panels are stationary in $V C R$, we proceed to test cointegration.

Regarding the methods for testing cointegration, the proposals of Pedroni (1999) and Westerlund (2007) were chosen. To do so, we select the VCR series as the dependent variable, while the $I E$ series would be the explanatory variable. 
Table 2. Cointegration between exports and specialization

(Pedroni's test results)

\begin{tabular}{|c|c|c|c|c|}
\hline Statistic & With trend & Without trend & $\begin{array}{c}\text { With trend } \\
\text { extraobs }^{\mathrm{a}}\end{array}$ & $\begin{array}{l}\text { With trend and } \\
\max \text { lags }{ }^{\text {b }}\end{array}$ \\
\hline Panel v & 1.182 & $1.542 * *$ & 1.525 & 1.182 \\
\hline Panel rho & $-1.652 * *$ & $-2.49^{*}$ & $-2.477^{*}$ & $-1.652 * *$ \\
\hline Panel t & $3.177^{*}$ & $-3.953 *$ & $-4.056^{*}$ & $-3.177^{*}$ \\
\hline Panel ADF & 0.879 & 1.099 & -0.074 & 1.493 \\
\hline Group rho & -0.102 & -0.313 & -0.471 & -0.102 \\
\hline Group $\mathrm{t}$ & $-4.194 *$ & $-4.763 *$ & $-4.77^{*}$ & $-4.194 *$ \\
\hline Group ADF & 1.235 & $2.543^{*}$ & -0.643 & $2.339 *$ \\
\hline
\end{tabular}

(Note) (i) ${ }^{\text {a }}$ if there is an unbalanced panel with observations missing for some of the variables (at the start or end of the sample) for certain individuals, the estimation includes the available observations from the missing years in the time means used for time demeaning.

(ii) ${ }^{\mathrm{b}}$ number of lags are based on Hannan-Quinn information criteria.

(iii) * RH0 at $1 \%$; ** RH0 at $5 \%$; *** RH0 at $10 \%$.

The results of statistical proposed by Pedroni (op. cit.) suggest cointegration. The statistic panel $t$ and group $t$ reject the null of no cointegration in each of the selected specifications. Panel rho statistic with and without trend, including observations available, also rejects the null, as well as group ADF do with and without trend or selecting the number of lags.

Like first generation unit root tests, this type of testing can lead to the conclusion that there is cointegration in the series, which is influenced by the existence of crossdependence between observations. Thus, we perform the proposal made by Westerlund (2007), a second-generation test that supports dynamic structures in the relationship between variables. In addition, since the panel covers a relatively long period in which there have been significant macroeconomic and structural reforms, it is possible that $I E$ exerts short- and long-term effects on $V C R$. Therefore, an error correction model is appropriate, because it allows estimating both effects and the speed of adjustment to equilibrium. 
Table 3. Panel cointegration between specialization and exports

(Westerlund (2007)'s test for 10 countries, 1985 2008)

\begin{tabular}{|c|c|c|c|c|}
\hline Statistics & $\begin{array}{c}\text { Lags (1) } \\
\text { Leads (0) } \\
\text { W(3)* }\end{array}$ & $\begin{array}{c}\text { Lags (1) } \\
\text { Leads (0) } \\
\text { W(4)* }\end{array}$ & $\begin{array}{c}\text { Lags (1) } \\
\text { Bootstrap } \\
\text { (100 reps) }\end{array}$ & Decision \\
\hline$G_{\tau}$ & $\begin{array}{c}-2.571 \\
-5.535 \\
(0.000)\end{array}$ & $\begin{array}{c}-2,571 \\
-5,535 \\
(0.000)\end{array}$ & $\begin{array}{c}-2.447 \\
-4.656 \\
(0.330)\end{array}$ & $\begin{array}{l}\text { RH0, series cointegrate. } \\
\text { NRH0 using Bootstrap }\end{array}$ \\
\hline$G_{a}$ & $\begin{array}{c}-10.210 \\
-3.511 \\
(0.000)\end{array}$ & $\begin{array}{c}-10.255 \\
-3.563 \\
(0.000)\end{array}$ & $\begin{array}{c}-10.424 \\
-3.761 \\
(0.180)\end{array}$ & $\begin{array}{l}\text { RH0, series cointegrate. } \\
\text { NRH0 using Bootstrap }\end{array}$ \\
\hline$P_{\tau}$ & $\begin{array}{c}-17.650 \\
-8.217 \\
(0.000)\end{array}$ & $\begin{array}{c}-17.656 \\
-8.223 \\
(0.000)\end{array}$ & $\begin{array}{c}-15.268 \\
-5.865 \\
(0.150)\end{array}$ & $\begin{array}{l}\text { RH0, series cointegrate, } \\
\text { NRH0 using Bootstrap }\end{array}$ \\
\hline$P_{a}$ & $\begin{array}{l}-11.689 \\
-10.108 \\
(0.000)\end{array}$ & $\begin{array}{c}-12.231 \\
-10.854 \\
(0.000)\end{array}$ & $\begin{array}{l}-9.368 \\
-6.909 \\
(0.140)\end{array}$ & $\begin{array}{l}\text { RH0, series cointegrate. } \\
\text { NRH0 using Bootstrap }\end{array}$ \\
\hline
\end{tabular}

(Note) (i) * Bartlett Kernel window width used in the estimation of long term semi-parametric variances.

(ii) H0: no cointegration, $G_{\tau}$ and $G_{a}$ check cointegration for each country individually and $P_{\tau}$ and $P_{a}$ check cointegration in panel globally.

(iii) Coefficient, $Z$ and $p$-values in parenthesis.

(iv) Other specifications could not be tried as the tests requires a long time horizon in order to consider more lags and/or leads.

Table 3 shows evidence of cointegration for the panel as a whole, and considering each cross section in particular. The speed of adjustment (in cases where the decision suggests that the series cointegrates) is near -0.6 , which is moderate. However, replications decrease the evidence in favor of a long-term relationship between location index and export pattern.

\section{A Stochastic Frontier Approach}

The extent to which organizations, regions, or countries take advantage from a given capability can be approached by efficiency analysis. This analysis implies comparing effective results with the results that should have been obtained from the full utilization 
of that potential (the frontier). In this case, the frontier is constructed from the country's potential in a given sector.

The analysis of potential trade utilization is based on stochastic frontier technique. This approach — originally proposed for estimating production frontiers in microeconomics - provides estimations of relative efficiency. Here, we try to identify if a country, or a given technology, is efficient in terms of translating its advantages (in proxy by specialization) into exports. Thus, the dependent variable $V C R$ is specified in terms of $I E$ on a model of the type:

$$
V C R_{i t}=\alpha+\beta I E_{i t}+\varepsilon_{i t} \quad i=1, \ldots, N ; t=1, \ldots, T
$$

where $\varepsilon_{i t}=v_{i t}-u_{i t}$. The term $\varepsilon$ is composed of two components: a symmetrical noise, normally distributed $\left(v_{i t} \sim \mathrm{N}\left[0, \sigma_{u}^{2}\right]\right)$, and a non-negative term of inefficiency that follows a normal truncated distribution $\left(u_{i t} \sim N+\left[\mu, \sigma_{u}^{2}\right]\right)$. Both terms of disturbance are independent of each other. For more details, see Kumbhakar and Lovell (2003).

The idea behind the stochastic frontier approach is that $I E$ sets an export potential that could be fully exploited and occur in exports, in which case $u_{i t}=0$ or, alternatively, it can also be underexploited, in which case, $u_{i t}>0$. Thus, the estimate stochastic frontier involves imposing the restriction that the term associated with inefficiency should invariably take non-negative values ${ }^{7}$.

In stochastic frontier models with panel data, there are two possible parameterizations for the inefficiency term: time variant or invariant. In the former, an equation must be entered in order to model the temporal sequence for $u_{i t}$. Battese and Coelli (1992) propose a model, where $u_{i t}$ is defined as:

$$
u_{i t}=u_{i} \mathrm{e}^{\eta(t-T)}
$$

where $T$ represents the last period of the panel, $\eta$ is a vector of parameters to be estimated, and $u_{i}$ the sample average level of inefficiency or the mean distance to the estimated stochastic frontier. If $\eta=0$, the model does not depend on time, and the most appropriate decision is to use a model with static inefficiency. If $\eta>0$ inefficiency, it is increasing, and vice versa.

\footnotetext{
${ }^{7}$ Traditionally in models using cross-section data, the inefficiency term is assumed to follow a mean normal, truncated mean normal, exponential, or gamma distribution. Estimates of stochastic frontier in panel data usually assume the truncated normal distribution. In practice, outcomes rarely differ depending on the type of distribution used, as cumulative density functions differ only at the extreme.
} 
Since the model is based on panel data with two dimensions-cross-section and time series - and the problem here analyzed contains three dimensions (country, type of manufacturing technology, and time), the estimate requires setting one of the two crosssectional dimensions. Thus, two variants were tried: one in which technology is given, and the resulting panel contains observations per country per year; and another one where the country is given, and observations vary by technology and by year.

Table 4 summarizes the results of the model. It should be noted that the results of Paraguay are excluded from the table. Additionally, in the case of Venezuela, the option that allows for $u_{i t}$ variability in time is also omitted, because the objective function was not concave, and the procedure is unable to find an optimal value.

The results obtained considering a frontier estimation for each country (i.e., where $i$ stands for the sector in the panel) shows that in four of the eight countries analyzed, the potential benefits are significant to explain the intra-regional export position. However, the potential of the economies in each sector do not appear to be fully exploited by exports. In most cases, in countries where specialization becomes significant to boost exports, the magnitude of $\beta$ does not exceed 0.3. Additionally, the evidence favors temporal variations in inefficiency. Except in Argentina, the other countries face a rising inefficiency over time.

Some explanations are required to clarify some confusing results. For instance, the low average value of $\beta$ must not be interpreted as a sign of country's or sector's inefficiency in translating specialization into exports - that specialization may be transferred to internal or foreign markets other than regional ones. Thus, a given country or sector can exhibit low $\beta$ with high efficiency scores, and some other can display high $\beta$ with low efficiency.

In particular, Peru is the economy that most exploited its export potential, as $\beta$ is substantially higher $(0.63)$ than the rest of its partners $(\beta<0.3)$, which was significant. Although the sign of $\eta$ indicates that inefficiency is growing, it has the lowest coefficient $(\eta=0.0349)$ in the group.

Values and statistical significance for $\eta$ allow us to state that Bolivia and Peru increased their efficiency, as their $\beta$ coefficients for possible settings were significant. 
Table 4. Exports driven by specialization: a stochastic frontier estimation

\begin{tabular}{|c|c|c|c|c|}
\hline \multirow[t]{2}{*}{ Country } & \multirow{2}{*}{$\begin{array}{c}\begin{array}{c}\text { Time } \\
\text { invariant }\end{array} \\
\beta\end{array}$} & \multicolumn{2}{|c|}{ Time variant } & \multirow[t]{2}{*}{$\begin{array}{c}\text { Number of } \\
\text { observations, } \\
\quad \boldsymbol{N} \times \boldsymbol{T}\end{array}$} \\
\hline & & $\beta$ & $\eta$ & \\
\hline Argentina & $\begin{array}{l}0.0412 \\
(0.592)\end{array}$ & $\begin{array}{c}0.2160 * \\
(0.000)\end{array}$ & $\begin{array}{c}-0.0281 * \\
(0.000)\end{array}$ & 96 \\
\hline Bolivia & $\begin{array}{c}0.1634 * * \\
(0.076)\end{array}$ & $\begin{array}{c}0.3096 * * \\
(0.044)\end{array}$ & $\begin{array}{c}0.0359 * \\
(0.000)\end{array}$ & 68 \\
\hline Brazil & $\begin{array}{l}0.1304 \\
(0.308)\end{array}$ & $\begin{array}{l}0.1742 \\
(0.226)\end{array}$ & $\begin{array}{l}-0.0028 \\
(0.440)\end{array}$ & 92 \\
\hline Chile & $\begin{array}{c}0.1791 * * \\
(0.098)\end{array}$ & $\begin{array}{l}-0.0415 \\
(0.645)\end{array}$ & $\begin{array}{c}0.0219^{*} \\
(0.000)\end{array}$ & 92 \\
\hline Colombia & $\begin{array}{l}-0.0772 \\
(0.315)\end{array}$ & $\begin{array}{l}-0.0842 \\
(0.272)\end{array}$ & $\begin{array}{l}0.0058 \\
(0.126)\end{array}$ & 96 \\
\hline Ecuador & $\begin{array}{c}-0.5629+ \\
(0.000)\end{array}$ & $\begin{array}{c}-0.2866+ \\
(0.035)\end{array}$ & $\begin{array}{c}0.0406^{*} \\
(0.004)\end{array}$ & 40 \\
\hline Peru & $\begin{array}{l}0.6455^{*} \\
(0.000)\end{array}$ & $\begin{array}{c}0.6282 * \\
(0.000)\end{array}$ & $\begin{array}{c}0.0349 * \\
(0.000)\end{array}$ & 76 \\
\hline Uruguay & $\begin{array}{l}0.0948 \\
(0.247)\end{array}$ & $\begin{array}{c}0.1662 * * \\
(0.058)\end{array}$ & $\begin{array}{l}0.0148 \\
(0.124)\end{array}$ & 68 \\
\hline Venezuela & $\begin{array}{l}-0.7025^{\mathrm{a}} \\
(0.009)\end{array}$ & $\mathrm{b}$ & $\mathrm{b}$ & 56 \\
\hline High technology & $\begin{array}{c}4.86 \mathrm{e}-08 \\
(0.519)\end{array}$ & $\begin{array}{c}7.62 \mathrm{e}-08 \\
(0.215)\end{array}$ & $\begin{array}{c}0.0170 * \\
(0.004)\end{array}$ & 181 \\
\hline Mid technology & $\begin{array}{l}0.0644 \\
(0.375)\end{array}$ & $\begin{array}{l}0.0272 \\
(0.712)\end{array}$ & $\begin{array}{c}-0.0064 * * * \\
(0.091)\end{array}$ & 181 \\
\hline Low technology & $\begin{array}{l}0.1047 \\
(0.291)\end{array}$ & $\begin{array}{c}0.1434 * * \\
(0.074)\end{array}$ & $\begin{array}{c}0.0343^{*} \\
(0.000)\end{array}$ & 181 \\
\hline $\begin{array}{l}\text { Natural resources } \\
\text { based technology }\end{array}$ & $\begin{array}{l}-0.0791 \\
(0.195)\end{array}$ & $\begin{array}{l}-0.0828 \\
(0.187)\end{array}$ & $\begin{array}{l}0.0035 \\
(0.138)\end{array}$ & 181 \\
\hline
\end{tabular}

(Note) (i) $p$-values in brackets, 2 tails.

(ii) a: Relevant at $1 \%$ and $5 \%$, but with sign contrary to expected.

(iii) b: models for Paraguay and Venezuela could not be estimated as objective function was not concave for both specifications.

(iv) * $\mathrm{RH} 0$ at $1 \%$; ** $\mathrm{RH} 0$ at $5 \%$; *** $\mathrm{RH} 0$ at $10 \%$. 
The case of Uruguay is particularly noteworthy here, whereby the model with static inefficiency does not record that $I E$ will significantly impact $V C R$. Here, the specification with variant inefficiency does not find $\eta$ as significant (i.e., the correct specification would be static), but $\beta$ is significant and positive. One possible explanation for this contradictory result is the lack of sufficient observations in order to set stable results. In particular, the cases of Uruguay and Ecuador (where the parameter that accompanies $I E$ is significant, but its sign is contrary to the expected one) have the least number of observations, a condition that could affect the asymptotic properties of the estimators ${ }^{8}$.

On the other hand, the fact that countries such as Ecuador or Venezuela registered an opposite sign than expected could also be due to several factors that are not necessarily econometric in nature. These factors include a manufacturing specialization oriented to the domestic market or policies unfavorable to industrial goods' exports (e.g., exchange rate appreciation).

When the $i$-th dimension of the panel represents countries (for a given sector), the results indicate that the coefficient of $I E$ variable is not significant (except in low technology, which is significant at 5 percent). Again, this suggests that effective trade patterns are not driven by the advantages.

In this methodology the error term, $u_{i t}$, measures (in)efficiency in the use of a country's capability. In the case of low-tech manufacturing, efficiency has been increasing over time in all countries under study. In this sector, there are countries with high inefficiency (e.g., Bolivia, Peru, Venezuela, and Ecuador), and others where the exploitation of advantages is higher (e.g., Chile and Colombia).

Figure 1 shows countries with similar (in)efficiency estimates, exhibiting inefficiency clubs with two or three countries each. In spite of insufficient country data, the growing and sustained trend-at least in low-tech manufacturing-over time of efficiency in exploiting its potential is clear. Nevertheless, a majority of the economies are still underexploiting their export potential by more than 20 percent.

\footnotetext{
${ }^{8}$ In econometrics, a small number of observations is known as a micronumerosity problem, one of whose symptoms is the instability of the coefficients, the lack of individual significance, or signs contrary to the expected ones.
} 
Figure 1. Efficiency scores for intra-regional exports

(in low-tech manufacturing, by country)

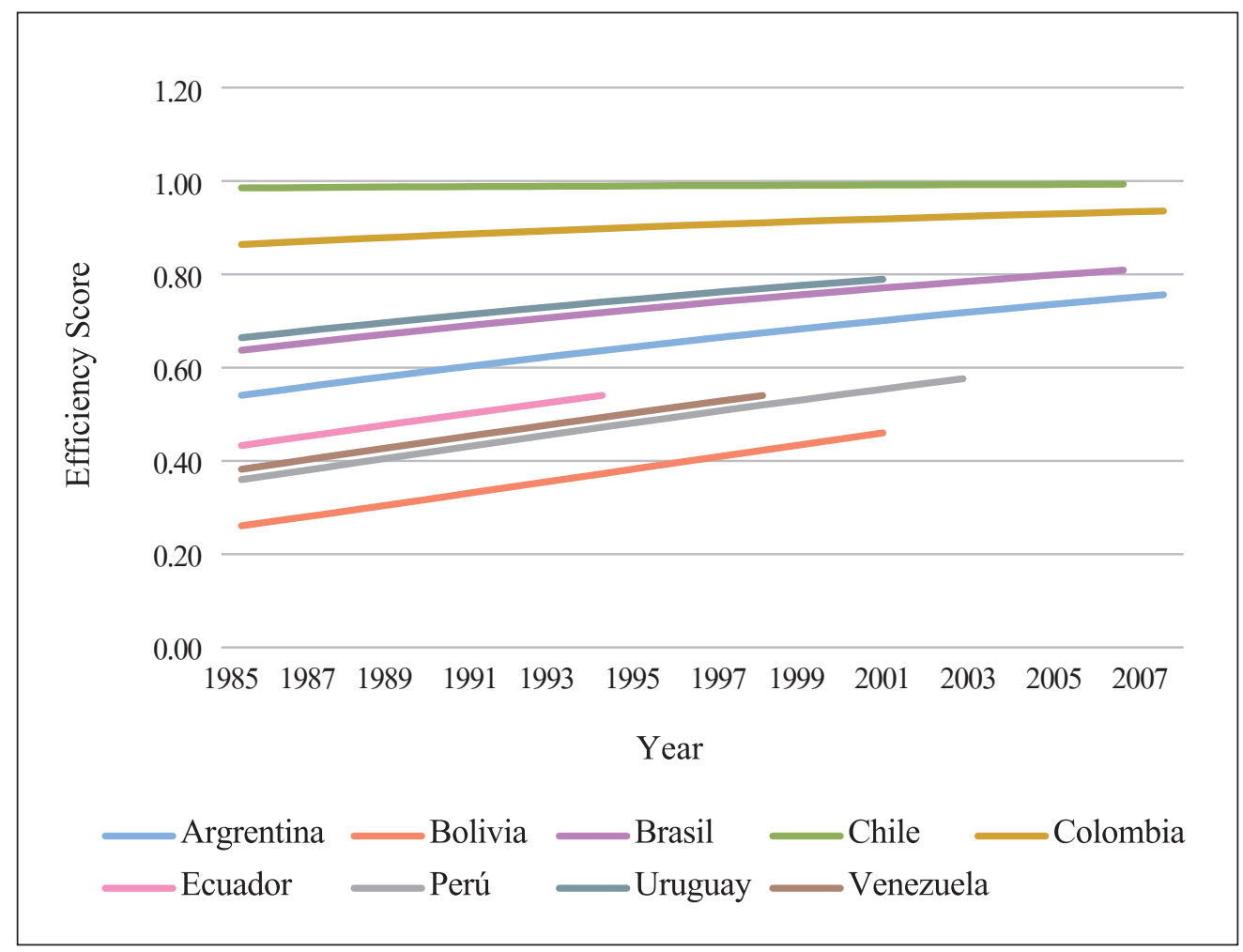

(Source) Authors' own.

Figure 2 exhibits variant efficiency scores, by sector, in those countries where the IE's coefficient was significant. Natural resource based manufacturing is the one with higher average efficiency scores in exploiting its potential. The picture is mixed in the rest of sectors and countries as countries with upward trends in efficiency also depart from very low scores.

In short, in the model with time variant inefficiency, Bolivia, Ecuador, and Peru have succeeded in transforming their manufacturing potential in exports to their regional partners. However, they still exhibit high inefficiency, especially in all technology sectors in Bolivia, the mid- and high-tech sectors in Chile, and low-tech and natural resourcebased sectors in Peru. In turn, Argentina is the economy with higher trade exploitation from its specialization, but figures show a downward trend.

Additionally, contrary to expectations, sectors where there was more transformation 
from specialization to exports do not record a particular specialization.

The results obtained in the time variant model do not differ substantially from the invariant specification for inefficiency. When fixing the model by country, there is an increasing trend in efficiency in the less efficient sectors, and the rest of them form a group with stable trends in inefficiency evolution.

Finally, the mid-tech and natural resource-based sectors have higher efficiency in the use of their potential, except for Argentina, where high-tech manufactured goods also display high efficiency scores.

Figure 2. Evolution of efficiency scores by country and sector

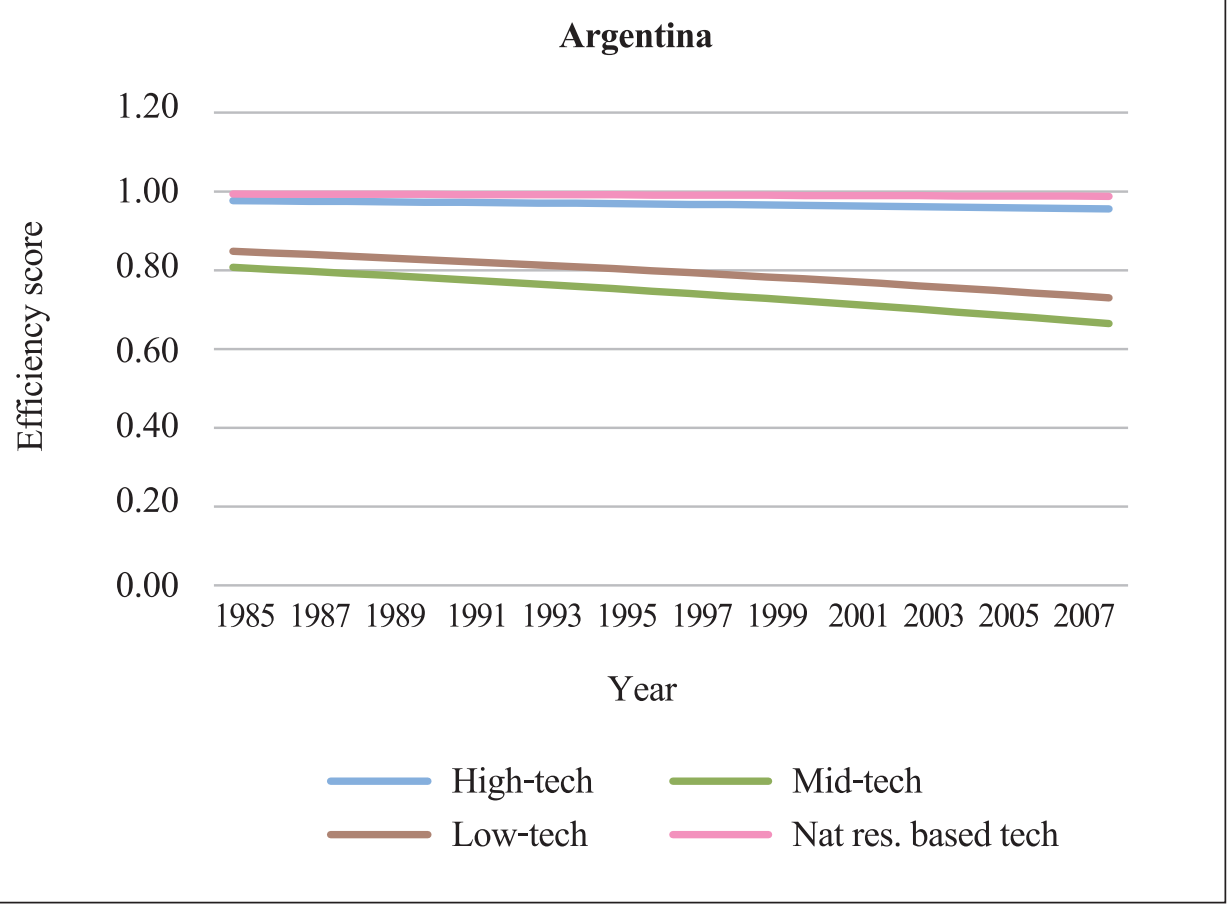



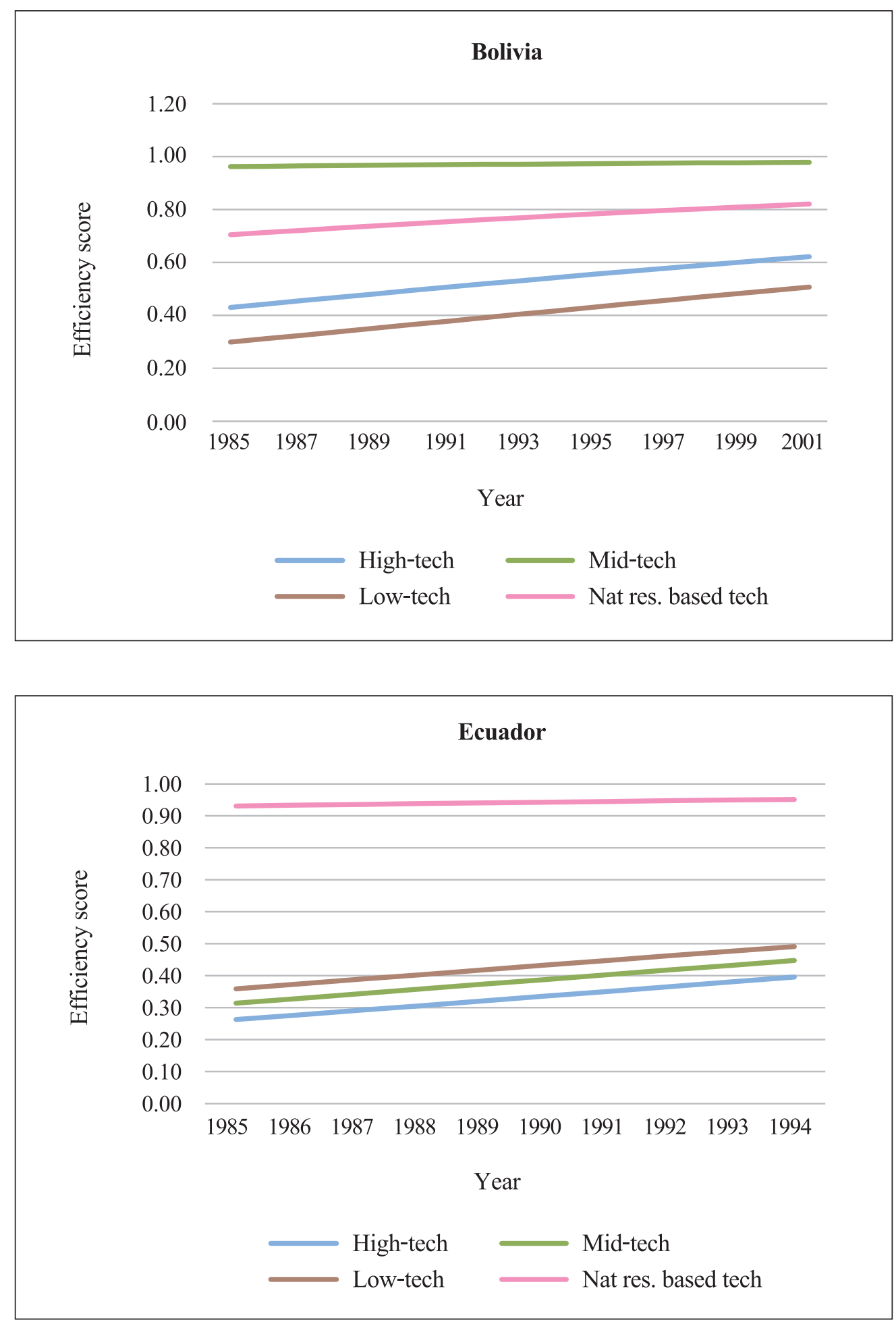

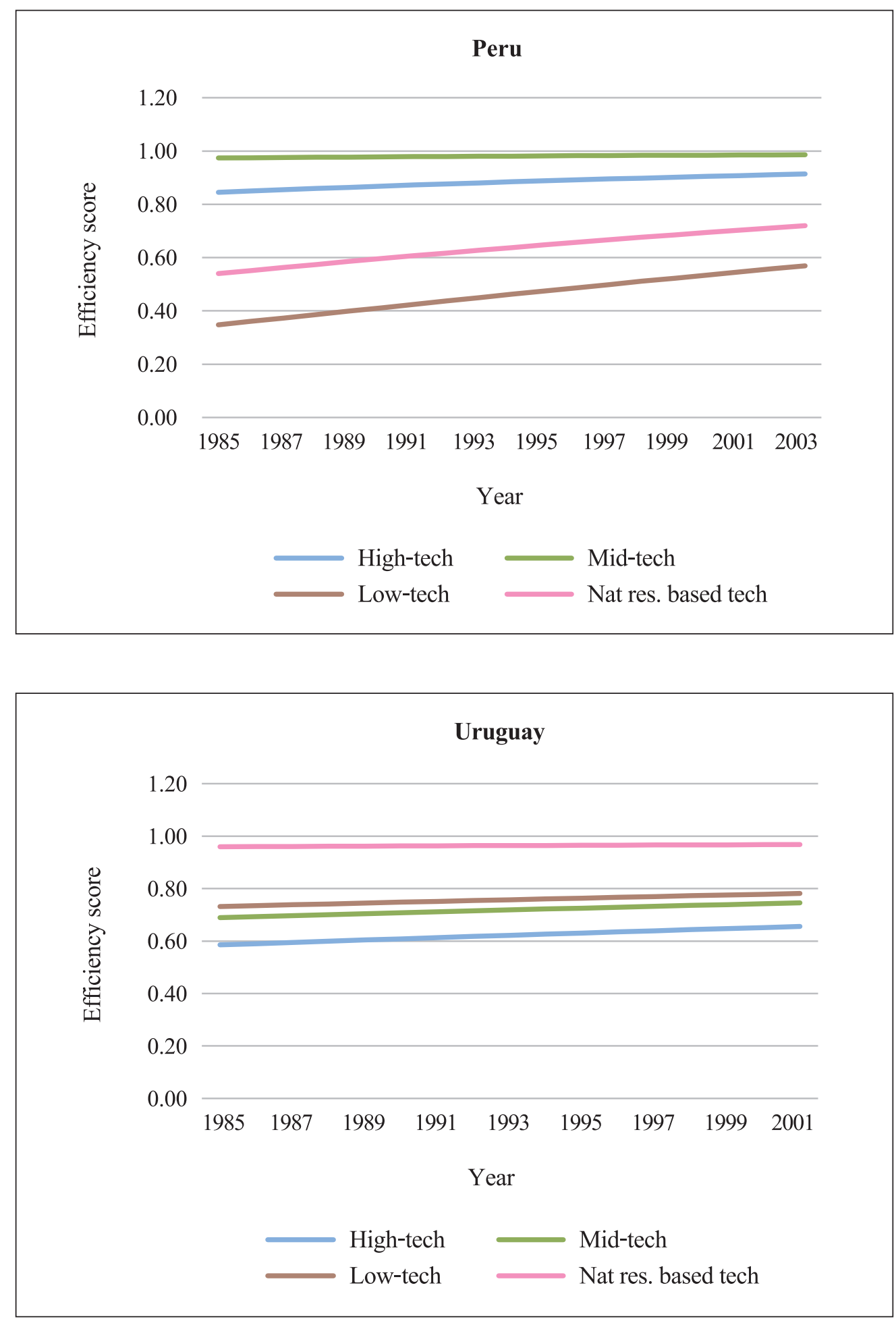

(Note) High-tech: high technology sector; Mid-tech: mid technology sector; Low tech: low technology sector; Nat. res based tech: Natural resources based technology sector. 


\section{Discussion and Final Remarks}

Economic integration agreements may generate benefits that cannot be appropriated symmetrically among participants. Regional economic integration has consequences on the behavior of industrial activity and its location, creating obstacles for some countries to participate fully as beneficiaries of that integration process. Additionally, “...both the size and wealth of the countries determine their ability to appropriate the benefits of an integration process" (Terra 2008, 4). The New Economic Geography emphasizes the importance of market size, as agglomeration processes are generated around the markets with larger sizes. On the other hand, the least developed and poorer countries are often left behind, being less able to exploit the opportunities offered by integration agreements.

In this paper, we study the contemporaneity of the changes in specialization patterns of South American countries with the signing of integration agreements. The aim was to check whether the potential of each country and sector to export (in terms of the specialization index) have been effectively exploited (in terms of higher relative exports). Moreover, we check if the change was contemporary or it followed the signing of trade agreements.

Results indicate that in all South American, countries except Venezuela, Colombia, and Ecuador, there could be contemporaneity between the date of break in one of the series and the signing of trade agreements. It is feasible to associate changes in specialization and exports series with trade agreements, but evidence suggests that it is also possible that the dates identified by the tests applied have diverse backgrounds, so that the contemporaneity of shocks in the series with the agreements is still hypothetical. Additional information is needed to monitor the effects of external variables on exports ${ }^{9}$.

The most important result observed is that after the signing of trade agreements, changes in the specialization or export structure of the country, if any, have been weak both in terms of breaks following those acts and sequence of emerging changes (from specialization to effective trade). Moreover, breaks in the series may also have been associated with other factors (e.g., the debt crisis in several countries in Latin America). The only exception to that global picture is the case of low-technology sector in Uruguay.

\footnotetext{
One drawback to be solved in future research is the narrowness of the time horizon of the information available to the economies of Paraguay and Ecuador. Therefore, and given the characteristics of the ZA test, they were not analyzed the results of these countries as they would not robust.
} 
Most of the countries studied moderately exploited their export potential. The ones with higher connection between specialization and export intensity also show high inefficiency. Peru differs slightly from that general picture as its $\beta$ coefficient (relating export potential with effective one) was substantially higher (0.63) than the rest of its partners $(\beta<0.3)$. Although efficiency is growing in most countries, it focuses on sectors with very low initial values. Argentina is the only country where efficiency exploiting its potential decreases over time.

According to the results, the potential of each country/sector to export certain manufactures has been, in some cases, executed inefficiently. The changes have been weak, and while they may be associated with the signing of a regional trade agreement, evidence suggests that it may be caused by other forces. While the region does not specialize in high-tech products, high-tech exports responded the most to regional trade alliances, and have proportionally gained more importance in trade in South America. Furthermore, changes in location/specialization following trade acts were not frequent, but when they occurred, they were concentrated in mid-tech manufacturing. Advantages exploitation exhibit an upward trend in low-tech manufacturing, but only three countries (Uruguay, Brazil, and Argentina) did significant progress, while the rest still exhibited high inefficiency in translating specialization into exports and/or were already highly efficient (Chile and Colombia).

However, methodological issues must be considered. Some countries recorded an opposite sign than expected in terms of export potential and revealed advantage. This could be due to several factors, including a manufacturing specialization oriented to the domestic market (specially marked in Venezuela) or policies unfavorable to exports of industrial goods (e.g., exchange rate appreciation). Another issue deserving attention is related with breaks in series. The ZA test endogenously identifies the date of possible cut off, but the effective impact of trade agreement should also consider the direction of the break in specialization and/or exports. Future research must complete the picture addressing this point. In cointegration testing, export advantage was taken as the dependent variable, and specialization as explanatory. Westerlund method assumes that the dependent variable has no effect on the regressor when it is plausible that they influence each other. Although there is literature that addresses this situation, it requires extensive work time ${ }^{10}$. In addition, cointegration tests do not support breaks. Westerlund and Edgerton (2008) and Costantini and Martini (2010) propose a panel co-integration

\footnotetext{
${ }^{10}$ The test proposed by Blackburne and Frank (2007) captures dynamic relationships and allows for cross-sectional heterogeneity. Usually, it is also applied to check bidirectionality, which requires a series of additional tests to check endogeneity and heterogeneity.
} 
test with breaks, but the routine is not yet available in traditional statistical packages; hence, its application is still limited.

Finally, the weak impact that RTAs have exerted on specialization and trade in South American may be attributed to various factors. First, intra-regional trade, although increasing, still accounts for a minor portion of total trade, where regional total exports are mainly primary products supplied to European and Asian markets. Second, the advantages of free trade and RTAs are still dubious for domestic firms not linked to global value chains (e.g., multinational firms and their network of suppliers and clients), for whom free trade only represents an opportunity insofar as they do not meet the threats of more efficient foreign competitors. Recent political events in the United Kingdom (Brexit) and the United States (President Trump's policy stance on free commerce) account for hesitation in certain parts of private business sectors regarding free trade and regional integration. The uncertainties of opportunities presented by trade agreements now emerging in developed countries were already present in South America from the beginning of the negotiations (Ruiz-Dana et al. 2007, Porta 2008). Moreover, figures presented by Fernandez-Stark et al. (2014) show the low penetration of global value chains in South America (with the exception of Mexico and Costa Rica), which explains the lack of impact of trade agreements in terms of specialization and export pattern.

As shown by Mancini (2013) through the case of Nicaraguan cheese, the recognition that trade agreements, even within the same country, offer both advantages and progress for some businesses but losses and drawbacks for others, hampers a selfless policy recommendation. On the one hand, the maintenance of trade barriers hinders the expansion of dynamic sectors and productivity gains. Conversely, if those who gain from integration are modern sectors, but with less capacity to generate employment than those who lose, social and political costs and could be high.

Received 19 March 2017, Revised 20 April 2017, Accepted 27 April 2017 


\section{References}

Balassa, Bela. "Trade Liberalization and Revealed Comparative Advantage". Manchester School 33 (1965): 99-123.

Battese, G. E. and Coelli, T. J. "Frontier production functions, technical efficiency and panel data: with application to paddy farmers in India". Netherlands: Springer (1992)

Baumann, Renato.. "Integration in Latin America. Trends and Challenges". Cepal Working Paper LC/BRS/R. 190. January (2008).

Blackburne, Ed and Frank, Mark. "Estimation of nonstationary heterogeneous panels". Stata Journal 7(2007): 197-208.

Bouzas, Roberto and da Motta Veiga, Pedro. "La experiencia Europea en el tratamiento de asimetrías estructurales y de políticas: Implicaciones para el Mercosur". In Asimetrías en el MERCOSUR: ¿Impedimento para el crecimiento?, ed. F. Massi, M. I. Terra, R. Bouzas, R., J. C. Arts, A. Lo Turco, and P. D. Veiga ,.131-185, Serie Red. Mercosur $N^{o} 12,2008$.

Bouzas, Roberto "Mecanismos para compensar los efectos de las asimetrías de la integración regional y la globalización: Lecciones para América Latina y el Caribe. El caso del Mercosur". (Paper presented at Seminario Global y Local: El Desafio del desarrollo regional en América Latina y el Caribe,Milán, Italia, March 22, 2003)

Clemente, Jesus, Montañés, Antonio. and Reyes, Marcelo. "Testing for a unit root in variables with a double change in the mean". Economics Letters 59(1998): 175-182.

Costantini, Valeria, and Martini, Chiara. "The causality between energy consumption and Economic growth: A multi-sectoral analysis using non-stationary cointegrated panel data". Energy Economics 32(2010): 591-603.

Estevadeordal, Antoni.. "Economic integration in the Americas. An unfinished agenda". In The Road to Hemispheric Cooperation. Beyond the Cartagena Summit of the Americas. Ed. T. Piccone Washington: The Brookings Institution,22-30, 2012.

Fernandez-Stark, Karina, Bamber, Penny and Gereffi, Gary. "Global value chains in Latin America. A development perspective for upgrading". In Global Value Chains and World Trade. Prospects and challenges for Latin America. Ed. R. Hernandez, J. Martinez-Piva and N. MulderSantiago: ELALC-German Cooperation,79-105, 2014. 
Forslid, Rikard and Wooton, Ian. "Comparative Advantage and the Location of Production". Review of International Economics, 11(2003): 588-603.

Gayá, Romina and Michalczewsky, Kathya. "El comercio intra-regional sudamericano. Patrón exportador y flujos intra-industriales”. BID Nota Técnica IDB TN No. 583. 2014.

Gonzalez, German and Delbianco, Fernando. "Apertura y productividad total de los factores: Análisis de la contemporaneidad en los quiebres estructurales para América Latina y el Caribe". Revista de Análisis Económico, 26(2011): 53-81.

Hoover, Jr. Edgard. "The Measurement of Industrial Localization”. The Review of Economics and Statistics, 18 (1936): 162-171.

Hurlin, Christophe and Mignon, Valerie. "Second Generation Panel Unit Root Tests". HAL Archives-Ouvertes No. 00159842, 2007.

Im, Kyung., Pesaran, Hashem and Shin, Yongcheol. "Testing for unit roots in heterogeneous panels". Journal of Econometrics, 115(2003): 53-74.

Imbs, Jean, Montenegro, Claudio and Wacziarg, Romain. "Economic integration and structural change". Paper presented in Political Economy Seminar, Toulouse, October 8, 2012.

Krugman, Paul and Venables, Anthony. "Integration, specialization, and adjustment". European Economic Review, 40 (1996): 959-967.

Kumbhakar, Subal., and Lovell, Knox. "Stochastic frontier analysis". Cambridge University Press, 2003.

Lall, Somik and Mengistae Taye. "Business Environment, Clustering and Industry Location: Evidence from Indian Cities". World Bank Policy Research Working Paper No. 3675, 2005.

Lall, Somik. "Exports of manufactures by developing countries: emerging patterns of trade and location". Oxford Review of Economic Policy, 11(1998): 54-73.

Lall, Somik. "The technological structure and performance of developing country manufactured exports, 1985- 98". Oxford Development Studies, 28(2000): 337-369.

Levin, Andrew, Lin, Chien-Fu and Chu, James. "Unit root tests in panel data: asymptotic and finite-sample properties". Journal of Econometrics, 108(2002): 1-24. 
Lo Turco, Alessia. "Integración regional Sur-Sur y desarrollo industrial asimétrico: el caso del Mercosur”. In Asimetrías en el MERCOSUR: ¿Impedimento para el crecimiento?, ed. F. Massi, M.I Terra, R. Bouzas, J. C. Artas, A. Lo Turco, and P. D. Veiga (2008): 87-130 Serie Red. Mercosur $N^{0} 12$.

Lumsdaine, Robin and Papell, David. "Multiple trend breaks and the unit-root hypothesis". Review of Economics \& Statistics 79(1997): 212-218.

Mancini, Maria Cecilia. "Geographical Indications in Latin America Value Chains: A "branding from below" strategy or a mechanism excluding the poorest?" Journal of Rural Studies; 32(2013): 295-306.

Ohara, Hidetaka. "A Unit Root Test With Multiple Trend Breaks: A Theory and an Application to US and Japanese Macroeconomic Time-Series". The Japanese Economic Review 50 (1999): 266-290.

CEPAL (Programa de Análisis de la Dinámica Industrial), CEPAL. División de Desarrollo Productivo y Empresarial retrieved from: http://www.cepal.org/software/cepal8b.html. Accessed September 20, 2015.

Pedroni, Peter. "Critical values for cointegration tests in heterogeneous panels with multiple regressors". Oxford Bulletin of Economics \& Statistics 61 (1999): 653-678.

Perron, Phillips. "Further evidence on breaking trend functions in macroeconomic variables". Journal of Econometrics 80(1997): 355-385.

Pesaran, Hashem. "A simple panel unit root test in the presence of cross-section dependence". Journal of Applied Econometrics 22 (2007): 265-312.

Pesaran, Hashem. "A simple panel unit root test in the presence of cross section dependence". Working Paper, Trinity College, Cambridge. 2003

Porta, Fernando. "La integración sudamericana en perspectiva. Problemas y dilemas". Cepal Colección Documentos de Proyectos. LC/BUE/W.32. 2008

Puga, Diego. "The rise and fall of regional inequalities". European Economic review, 43(1999): 303-334.

Puga, Diego and Venables, Anthony "Agglomeration and economic development: Import substitution vs. trade liberalization”. The Economic Journal, 109(1999): 292-311. Rodriguez Mendoza, Miguel. "Free trade agreements in South America. Trends, 
prospects and challenges". CAF Public Policy and Productive Transformation Series No. 7.2012

Ruiz-Dana, Alejandra, Goldschagg, Peter, Claro, Edmundo and Blanco, Hernan. "Regional integration, trade and conflict in Latin America". International Institute for Sustainable Development Working Paper, January. 2007

Terra, Marias Ines.. “Asimetrías en el Mercosur: ¿Un Obstáculo para el crecimiento?” In Asimetrías en el MERCOSUR: ¿Impedimento para el crecimiento? Ed. F. Massi, M.I Terra, R. Bouzas, J. C. Artas, A. Lo Turco, and P. D. Veiga, 2008, 2-30,Montevideo: Red. Mercosur.

United Nations, COMTRADE. Annual database, retrieved from https:/comtrade.un.org/ data/. Accessed August 12, 2015.

Venables, Anthony "Regional Integration Agreements: a force for convergence or divergence?” World Bank Policy Research Working Paper, No. 2260. 1999.

Venables, Anthony"Winners and losers from regional integration agreements". The Economic Journal, 113(2003): 747-761.

Venables, Anthony "Regionalism and Economic Development". In Bridges for Development. Policies and Institutions for Trade and Integration. Ed. Devlin, R. and Estevadeordal A. Washington DC: Inter-American Development Bank, 2003

Westerlund, Joakim. "Testing for error correction in panel data". Oxford Bulletin of Economics \& Statistics 69(2007): 709-748.

WITS (2011). Word Integrated Trade Solution. Retrieved from http://wits.worldbank. org/about_wits.html. Accessed March 19, 2017.

Westerlund, Joakim and Edgerton, David "A simple test for cointegration in dependent panels with structural breaks". Oxford Bulletin of Economics \& Statistics, 70(2008): 665704.

Zivot, Eric and Andrews, Donald. "Further evidence on the great crash, the oil-price shock, and the unit-root hypothesis". Journal of Business \& Economic Statistics 10(1992): 251-270. 


\begin{tabular}{|c|c|c|c|c|c|c|c|c|c|c|c|c|}
\hline & & 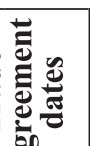 & & ஓे $\bar{\sigma}$ & స'。 & রి & 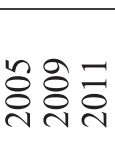 & & & 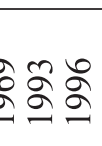 & 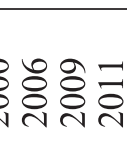 & \\
\hline & & .气 & & 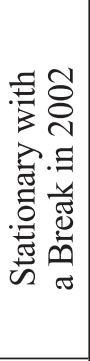 & 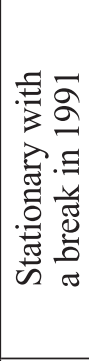 & 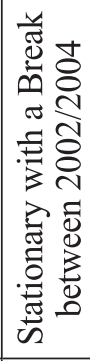 & 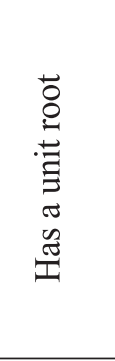 & & 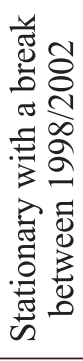 & 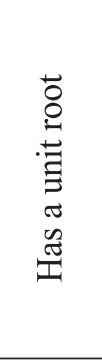 & 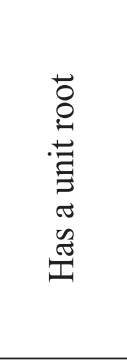 & 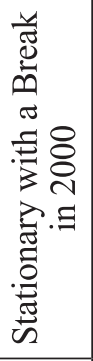 \\
\hline & & 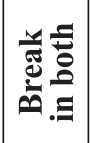 & & $\begin{array}{l}* \\
* \\
* \\
*\end{array}$ & $\begin{array}{l}* \\
\stackrel{*}{*} \underset{\Omega}{\sigma} \\
i\end{array}$ & 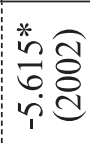 & $\begin{array}{l}\stackrel{8}{\&} \\
\stackrel{0}{+} \\
\stackrel{+}{1}\end{array}$ & & 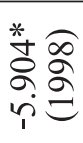 & $\begin{array}{l}\infty \\
\infty \\
\sim \\
p\end{array}$ & ্ָণ & 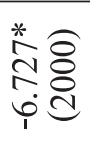 \\
\hline & $\begin{array}{l}\mathscr{u} \\
y\end{array}$ & 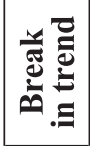 & & 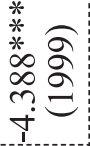 & 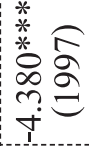 & 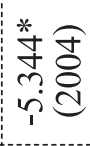 & $\frac{\mathscr{P}}{\dot{P}}$ & & 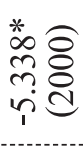 & 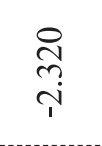 & 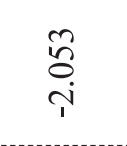 & 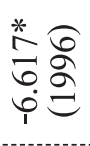 \\
\hline 苞 & & 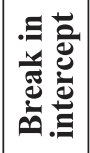 & & 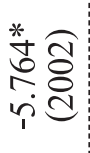 & 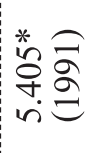 & $\begin{array}{l}\hat{尺} \\
\stackrel{f}{+} \\
\dot{T}\end{array}$ & 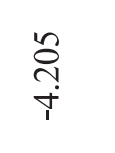 & & 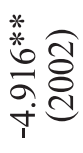 & $\begin{array}{l}\text { m } \\
m \\
m\end{array}$ & 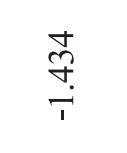 & 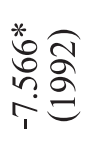 \\
\hline 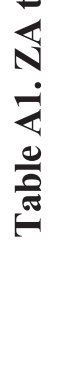 & & 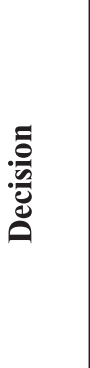 & & 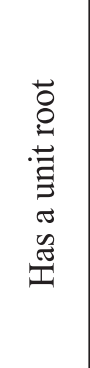 & 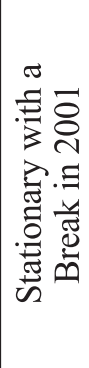 & 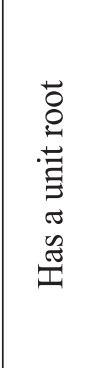 & 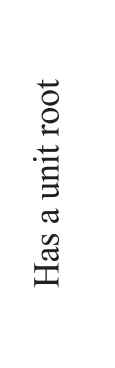 & & 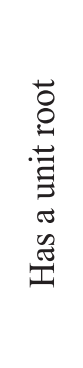 & 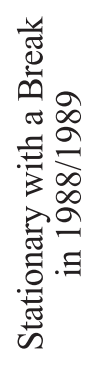 & 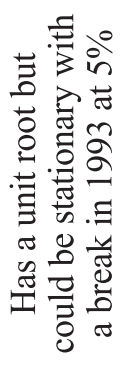 & 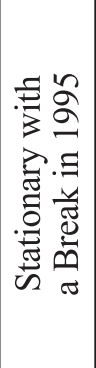 \\
\hline & & 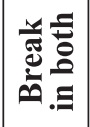 & & $\begin{array}{l}\stackrel{0}{0} \\
\text { i } \\
1\end{array}$ & 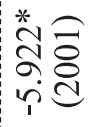 & $\begin{array}{l}\hat{\sigma} \\
\dot{\hat{r}}\end{array}$ & $\frac{\infty}{\infty}$ & & $\frac{m}{\sim}$ & 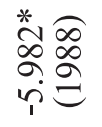 & 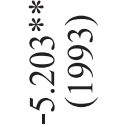 & 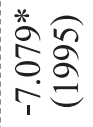 \\
\hline & 뙵 & 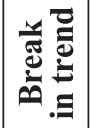 & & $\frac{2}{1}$ & $\begin{array}{l}m \\
\stackrel{m}{0} \\
\dot{p}\end{array}$ & $\begin{array}{l}\text { ते } \\
\text { ஸे } \\
\text { i }\end{array}$ & 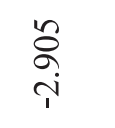 & & 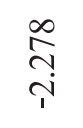 & 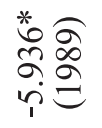 & 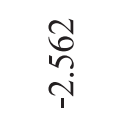 & 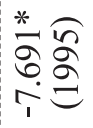 \\
\hline & & 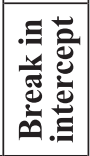 & & $\underset{+}{\stackrel{\Delta}{+}}$ & 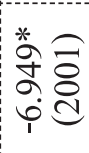 & $\begin{array}{l}\vec{\infty} \\
\infty \\
\dot{1}\end{array}$ & \begin{tabular}{l}
$\infty$ \\
\multirow{2}{r}{} \\
$\dot{r}$
\end{tabular} & & $\begin{array}{l}\stackrel{\sim}{\sim} \\
\stackrel{+}{+}\end{array}$ & 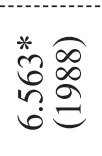 & $\frac{\infty}{\stackrel{n}{r}}$ & 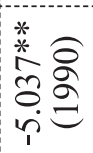 \\
\hline & & 产 & 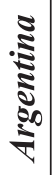 & 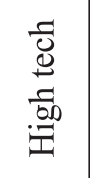 & $\begin{array}{l}\frac{\pi}{0} \\
\stackrel{\mathscr{E}}{0} \\
\stackrel{0}{\Sigma}\end{array}$ & 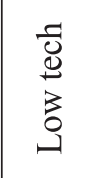 & 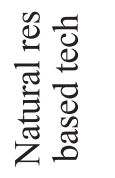 & 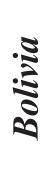 & 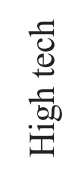 & $\begin{array}{l}\frac{\sigma}{0} \\
\stackrel{\Phi}{ \pm} \\
\dot{\Xi}\end{array}$ & 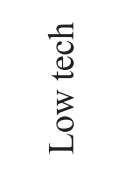 & 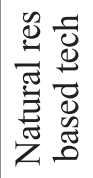 \\
\hline
\end{tabular}




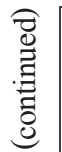

\begin{tabular}{|c|c|c|c|c|c|c|c|c|c|c|c|}
\hline \multicolumn{2}{|c|}{ 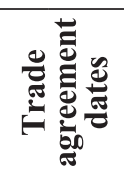 } & & \multicolumn{4}{|c|}{ 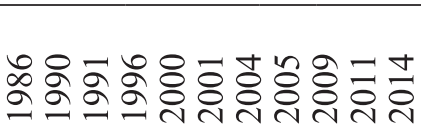 } & & \multicolumn{4}{|c|}{ 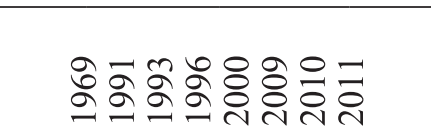 } \\
\hline & 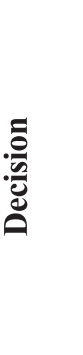 & & 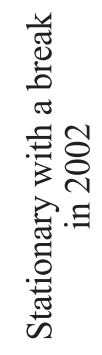 & 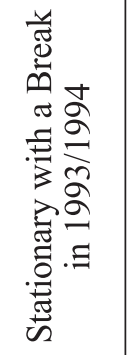 & 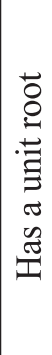 & 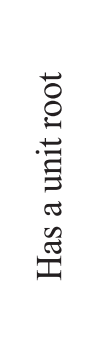 & & 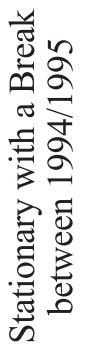 & 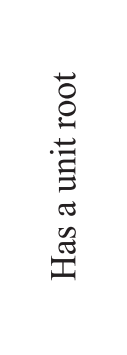 & 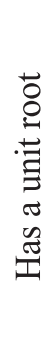 & 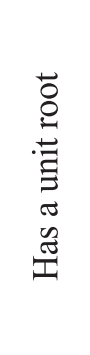 \\
\hline \multirow{3}{*}{$\stackrel{\sim}{v}$} & 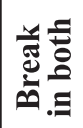 & & 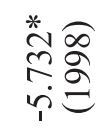 & 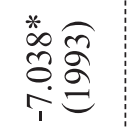 & $\frac{n}{n}$ & $\begin{array}{l}\infty \\
\infty \\
m\end{array}$ & & 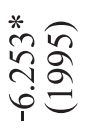 & $\begin{array}{l}\text { rె } \\
\infty \\
\dot{r}\end{array}$ & $\begin{array}{c}\hat{n} \\
\dot{r}\end{array}$ & $\begin{array}{l}\stackrel{n}{f} \\
\stackrel{f}{i}\end{array}$ \\
\hline & 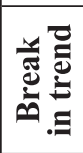 & & 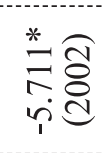 & 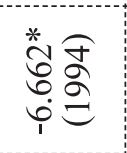 & $\begin{array}{c}\text { f } \\
\infty \\
r\end{array}$ & $\begin{array}{l}\text { bे } \\
\infty \\
\text { ri }\end{array}$ & & 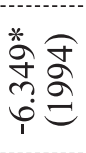 & 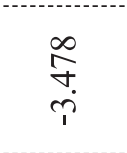 & $\begin{array}{l}\tilde{\sigma} \\
\tilde{b} \\
\dot{r}\end{array}$ & \begin{tabular}{l}
$*$ \\
$*$ \\
\multirow{2}{*}{$\widehat{\sigma}$} \\
\multirow{\gamma}{*}{}
\end{tabular} \\
\hline & 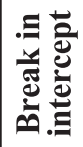 & & 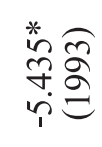 & 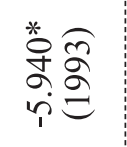 & 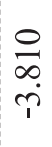 & $\frac{\infty}{n}$ & & 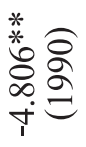 & $\begin{array}{l}\infty \\
\infty \\
\infty \\
1\end{array}$ & $\begin{array}{l}\vec{\sigma} \\
\dot{p}\end{array}$ & $\begin{array}{l}\vec{\infty} \\
\dot{p} \\
\dot{p}\end{array}$ \\
\hline \multicolumn{2}{|c|}{ 言 } & & 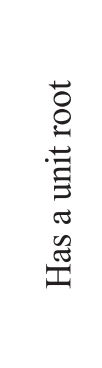 & 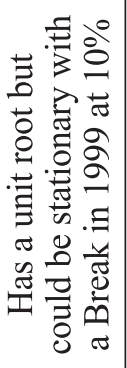 & 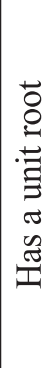 & 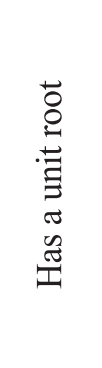 & & 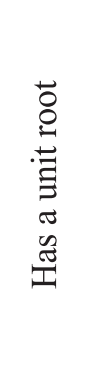 & 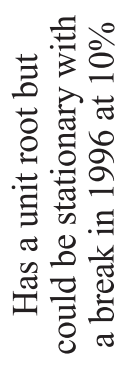 & 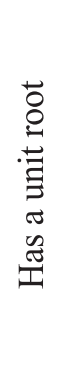 & 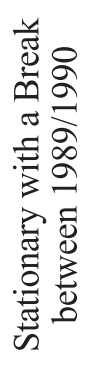 \\
\hline \multirow{3}{*}{ 될 } & 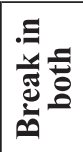 & & 竎 & 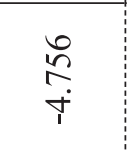 & $\frac{1}{\stackrel{1}{r}}$ & ते & & $\underset{i}{\stackrel{R}{R}}$ & 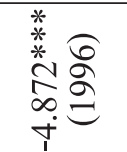 & 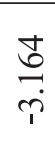 & $\begin{array}{l}\vec{\Omega} \\
\stackrel{+}{+}\end{array}$ \\
\hline & 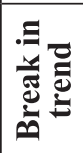 & & $\underset{\substack{\sim \\
i}}{\stackrel{\infty}{1}}$ & 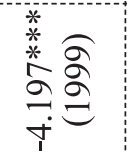 & $\begin{array}{l}\infty \\
\infty \\
i \\
i\end{array}$ & $\underset{⿱}{\stackrel{N}{N}}$ & & ז̂. & $\begin{array}{l}8 \\
\text { m. } \\
\text { i }\end{array}$ & $\underset{\substack{n \\
r}}{\frac{n}{f}}$ & 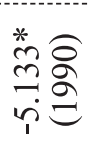 \\
\hline & 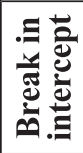 & & $\begin{array}{l}\vec{N} \\
\infty \\
\dot{1}\end{array}$ & $\underset{m}{m}$ & $\begin{array}{l}0 \\
\stackrel{n}{r} \\
r \\
1\end{array}$ & $\begin{array}{l}0 \\
\text { g̊ } \\
\dot{+}\end{array}$ & & $\frac{\text { ț }}{\stackrel{i}{i}}$ & 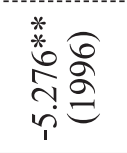 & $\begin{array}{l}\mathscr{n} \\
\infty \\
i \\
i\end{array}$ & 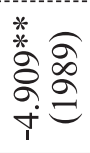 \\
\hline \multicolumn{2}{|c|}{ 言 } & 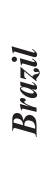 & 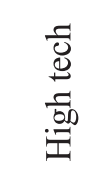 & 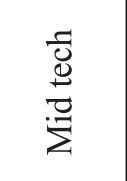 & 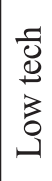 & 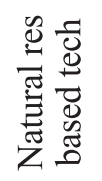 & 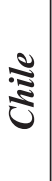 & 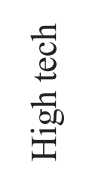 & 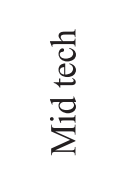 & $\begin{array}{l}\frac{1}{0} \\
\text { d } \\
3 \\
0 \\
0\end{array}$ & 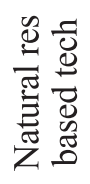 \\
\hline
\end{tabular}




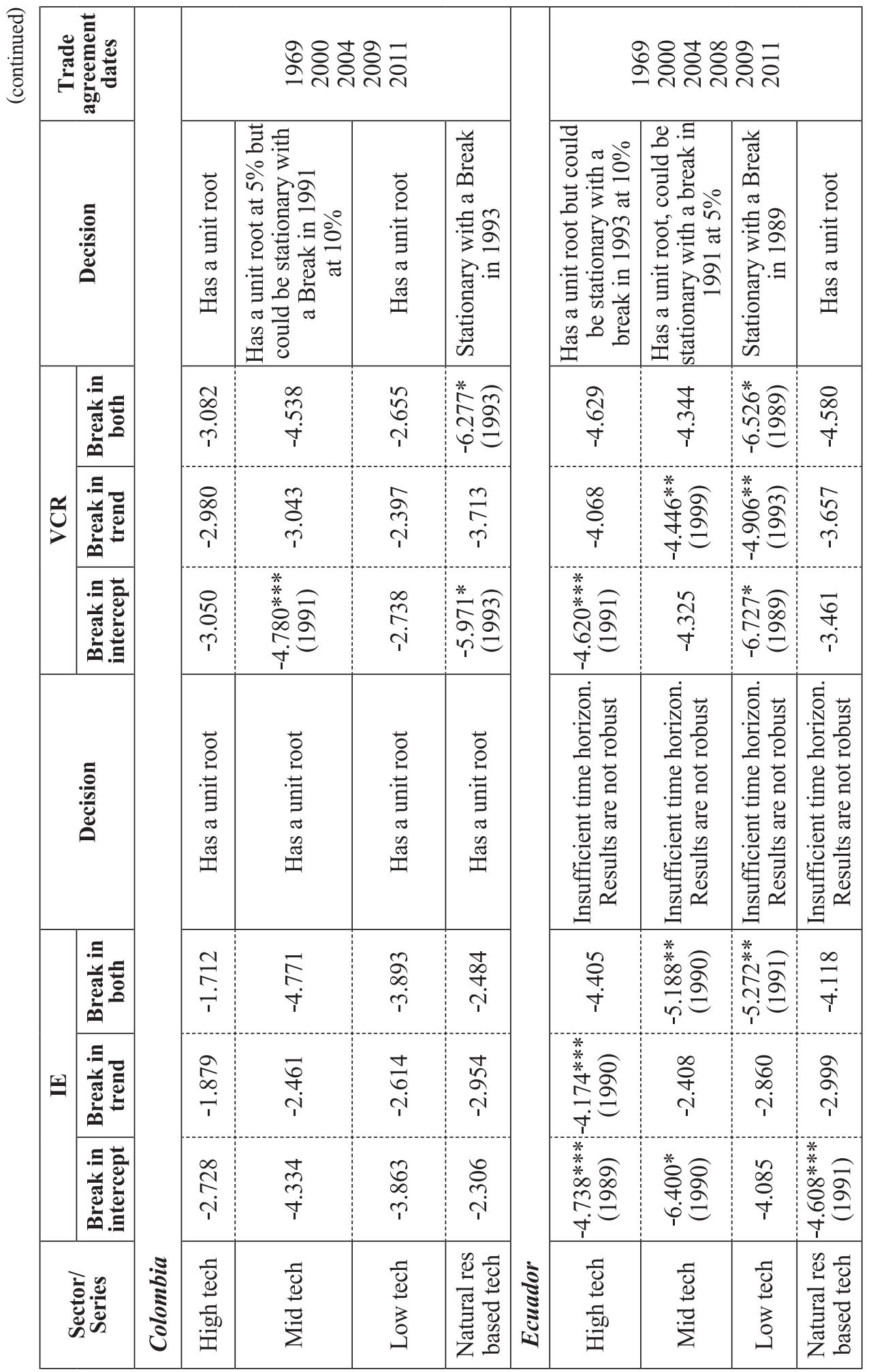


$j e i$

\begin{tabular}{|c|c|c|c|c|}
\hline 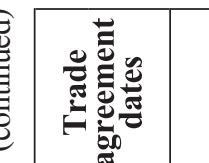 & 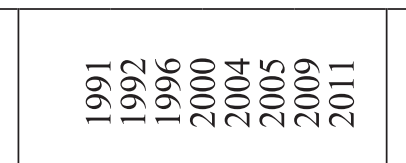 & 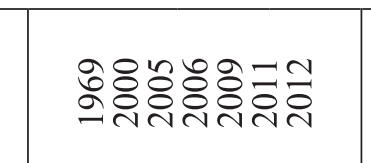 & 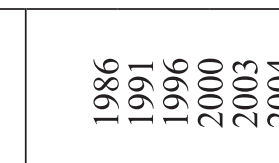 & 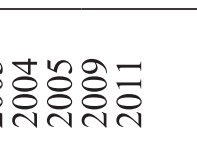 \\
\hline 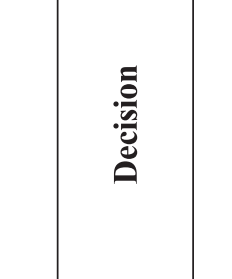 & 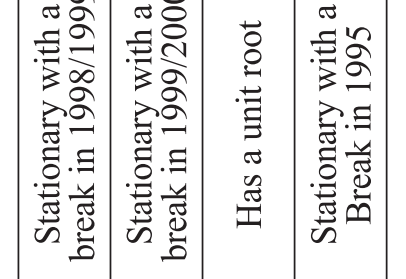 & 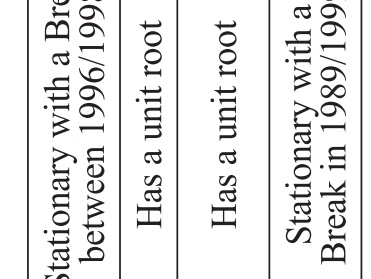 & 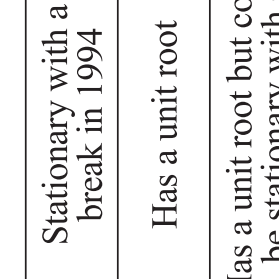 & \\
\hline$\tilde{m} \equiv$ & 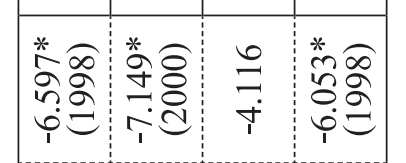 & 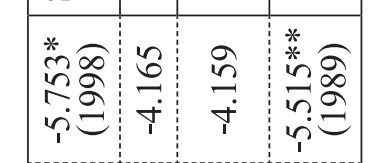 & 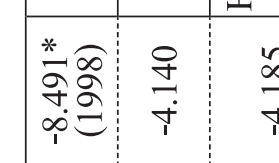 & 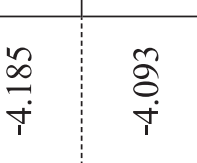 \\
\hline & 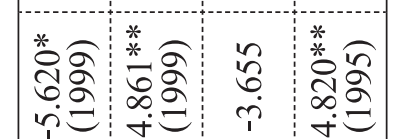 & 絖: & 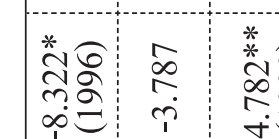 & 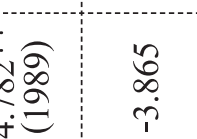 \\
\hline 5 & 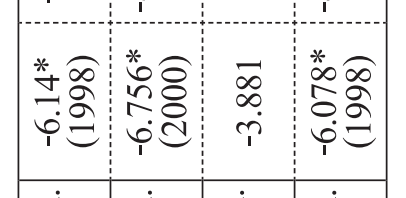 & 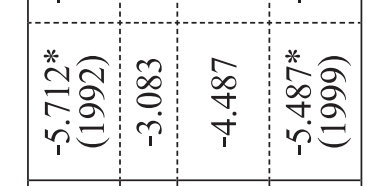 & 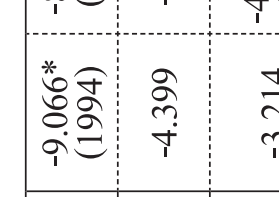 & 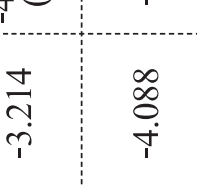 \\
\hline & & & 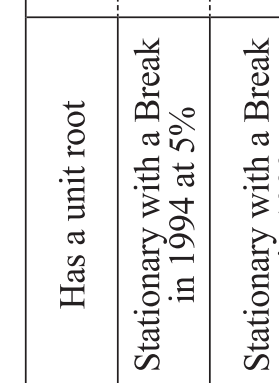 & \\
\hline 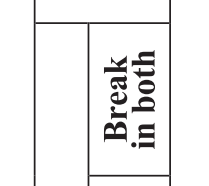 & 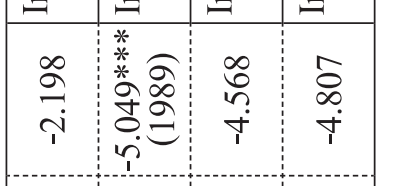 & 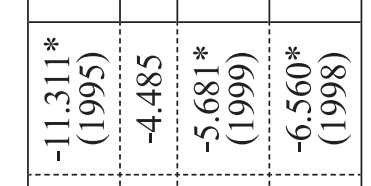 & 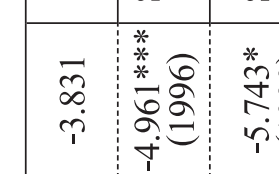 & 籍高 \\
\hline 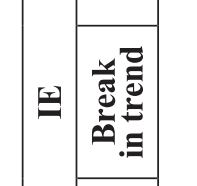 & 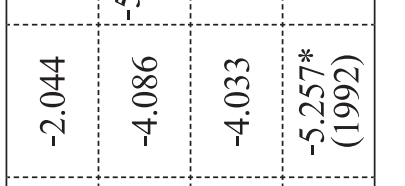 & 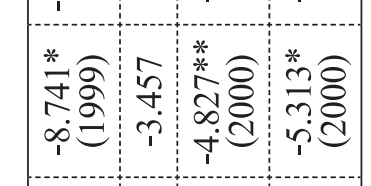 & 量解部 & 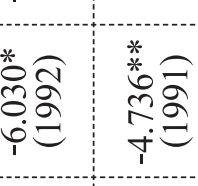 \\
\hline 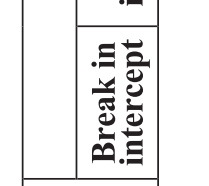 & 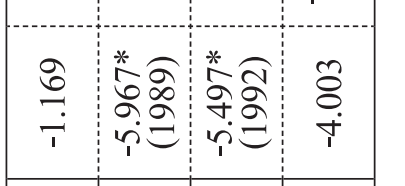 & 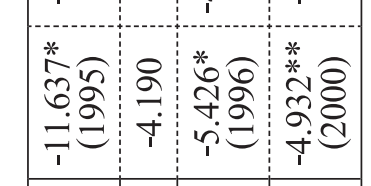 & 㝵艁言 & 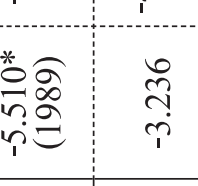 \\
\hline 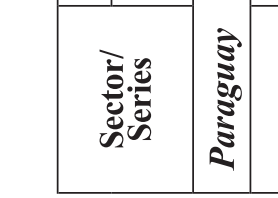 & & & $\mid$ & 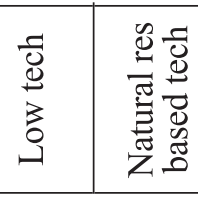 \\
\hline
\end{tabular}


氖

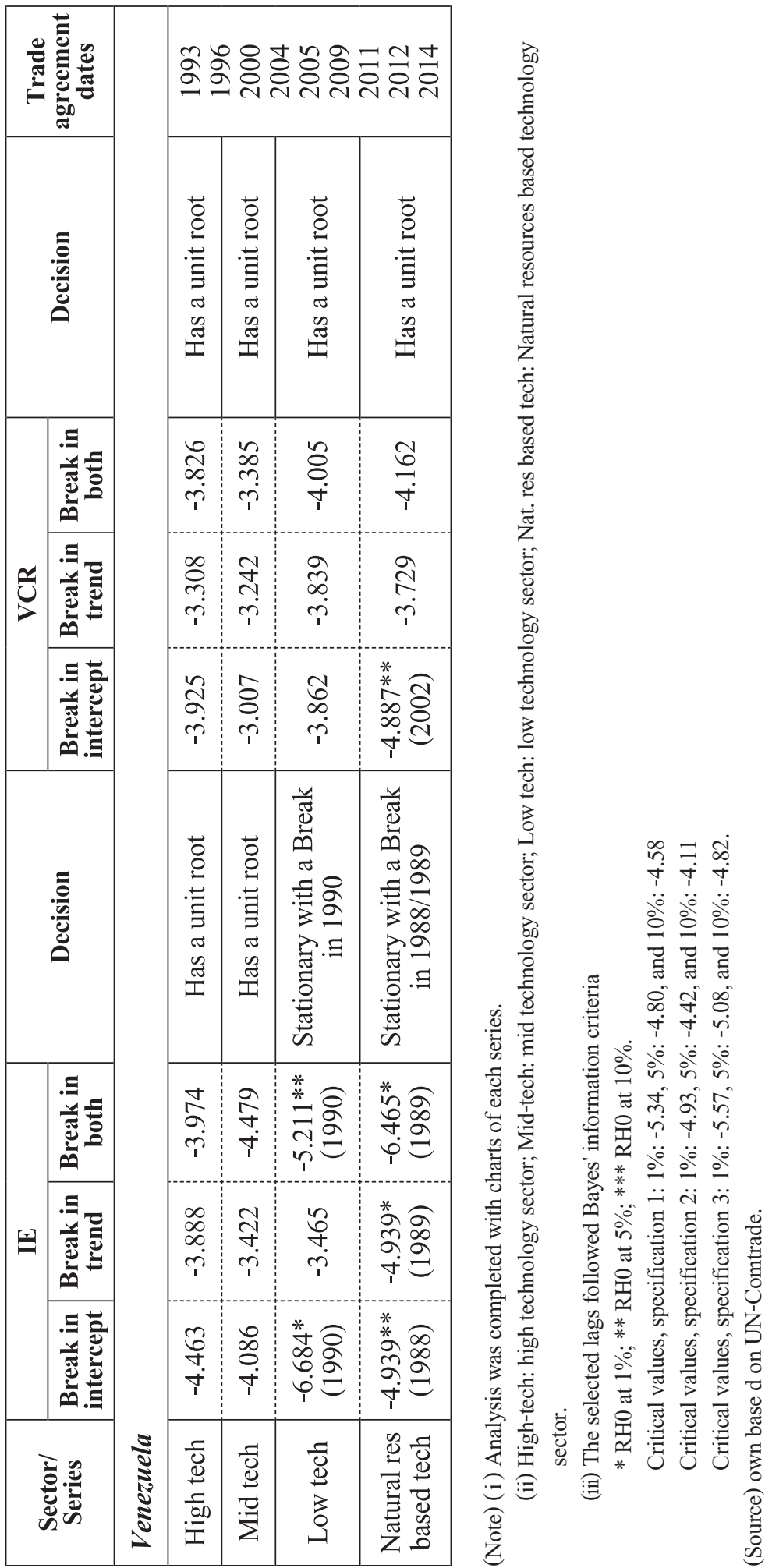


Figure A1. Specialization index series, $I E$
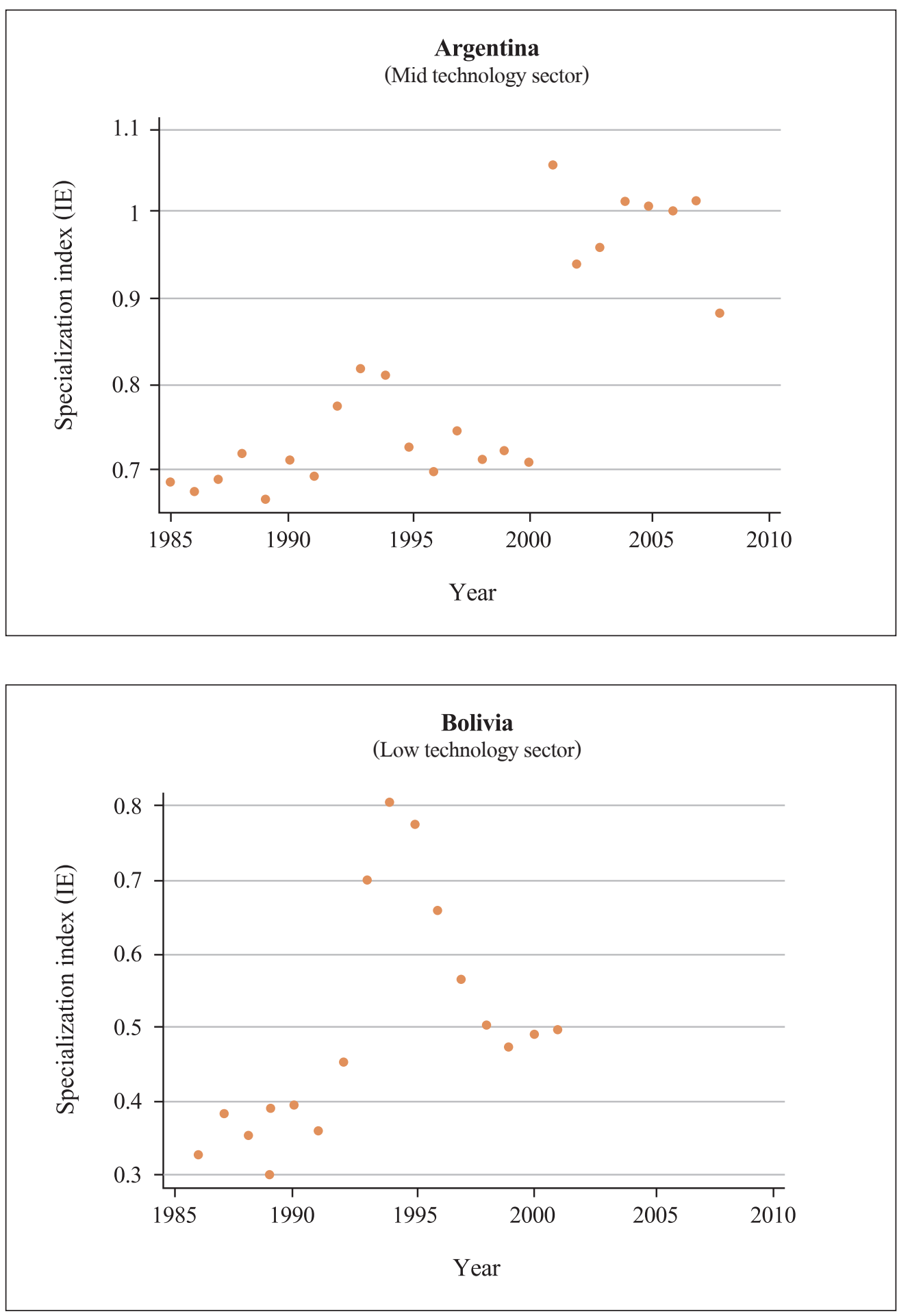

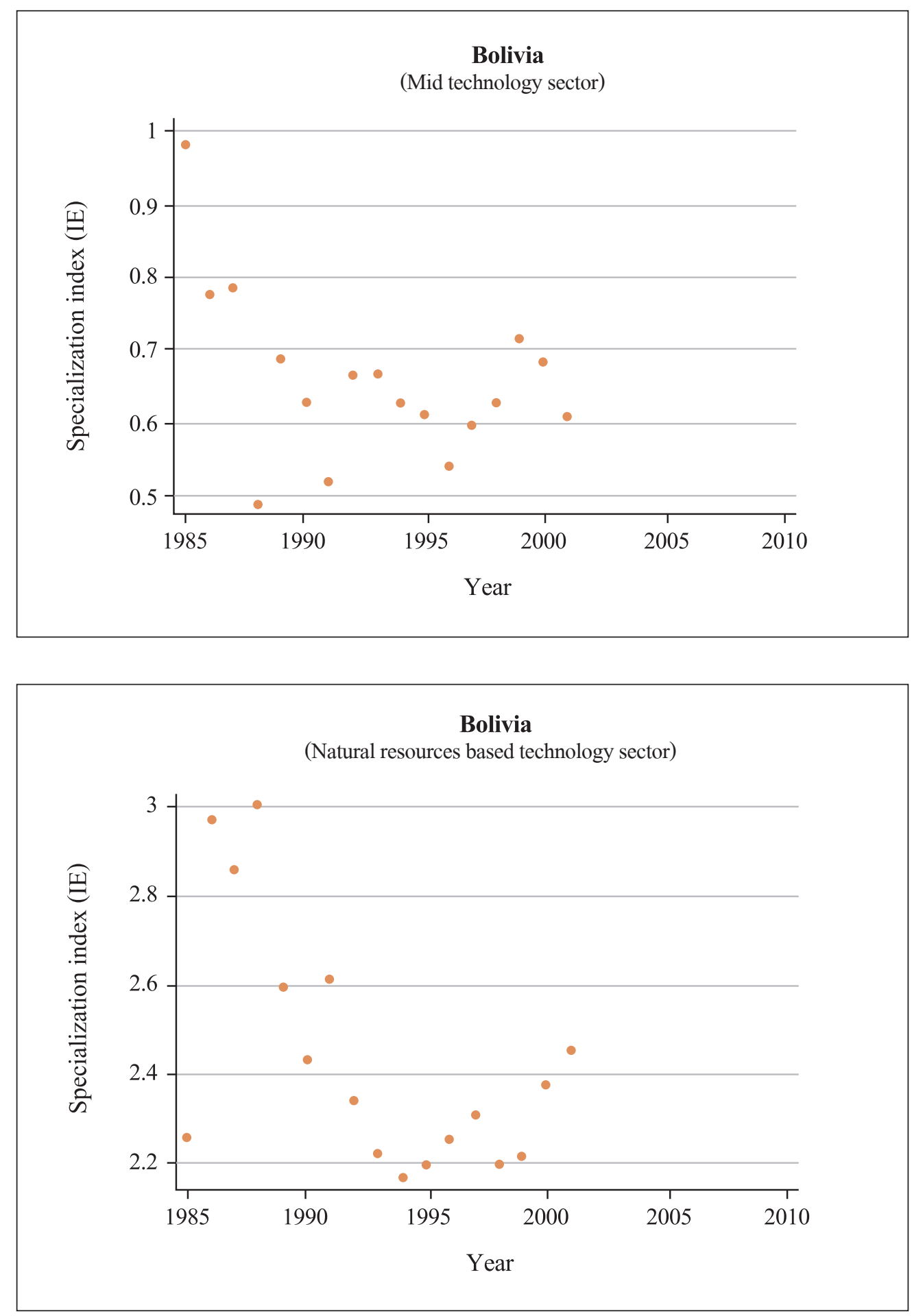

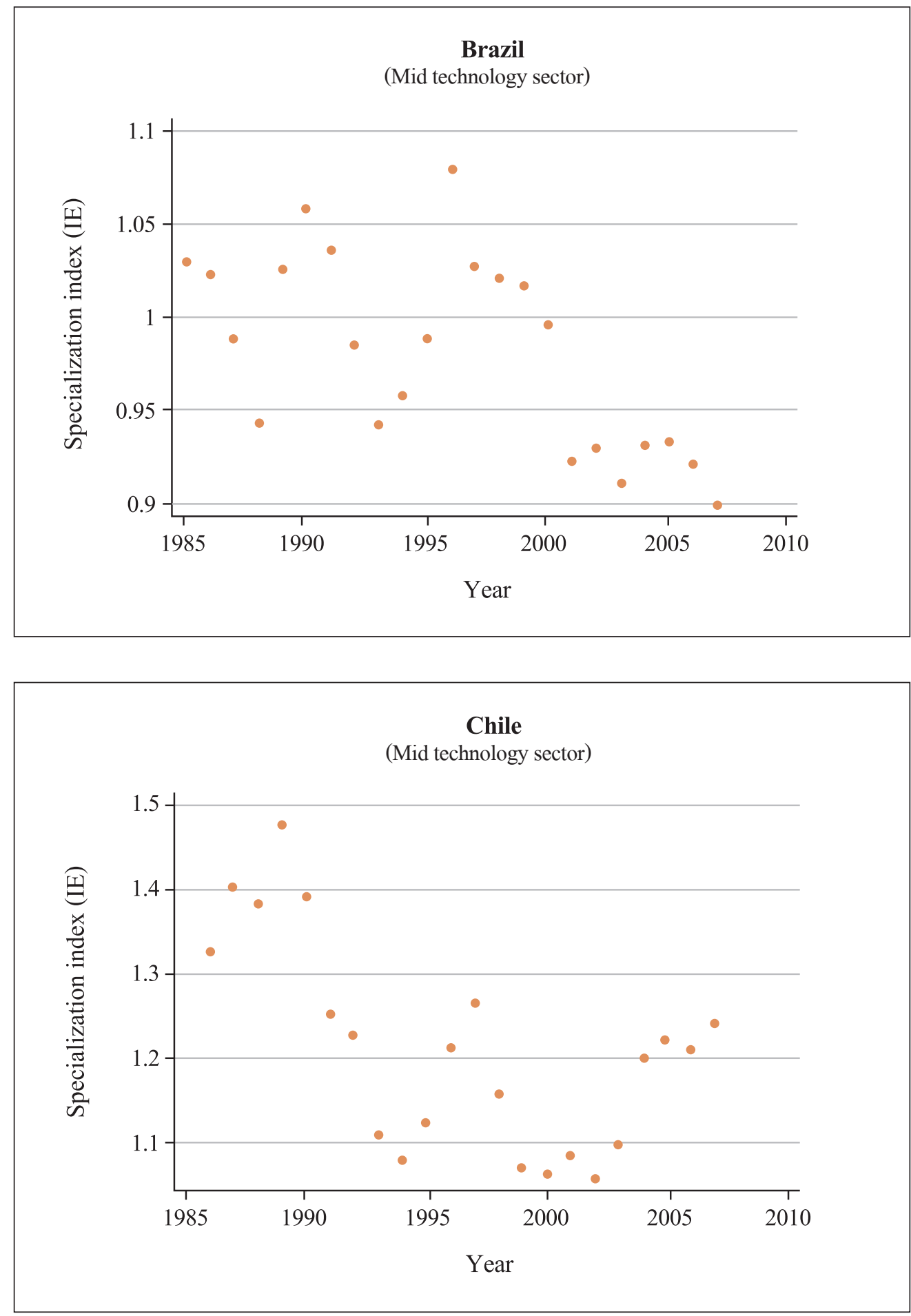


\section{Chile}

(Natural resources based technology sector)

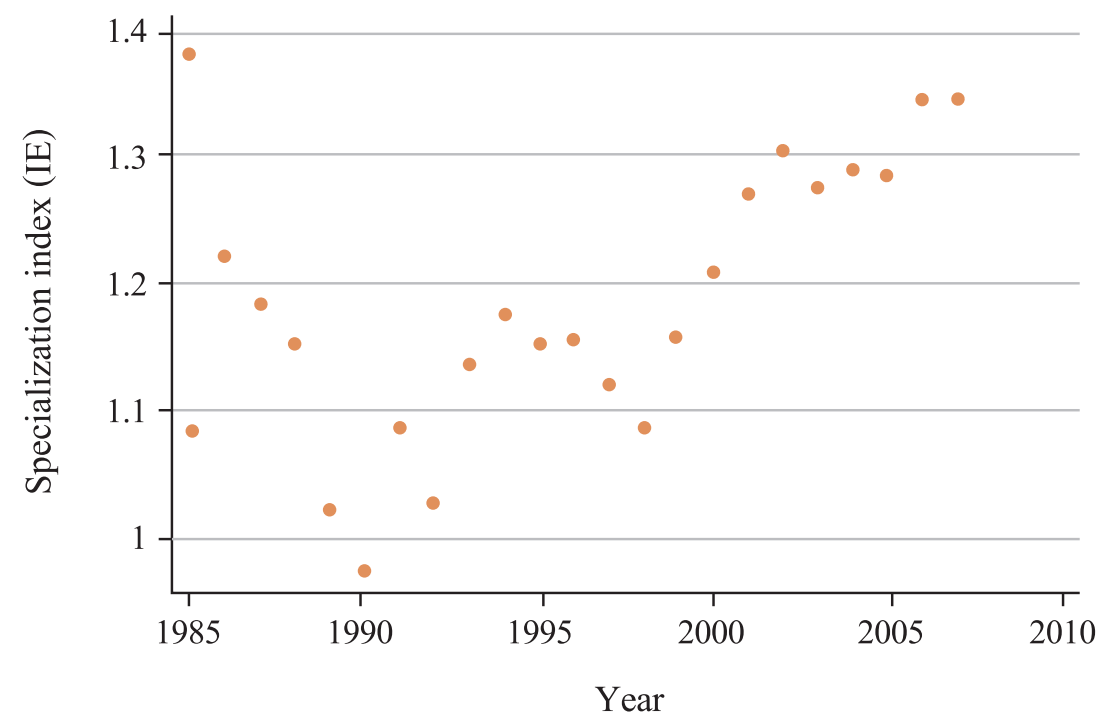

Peru

(High technology sector)

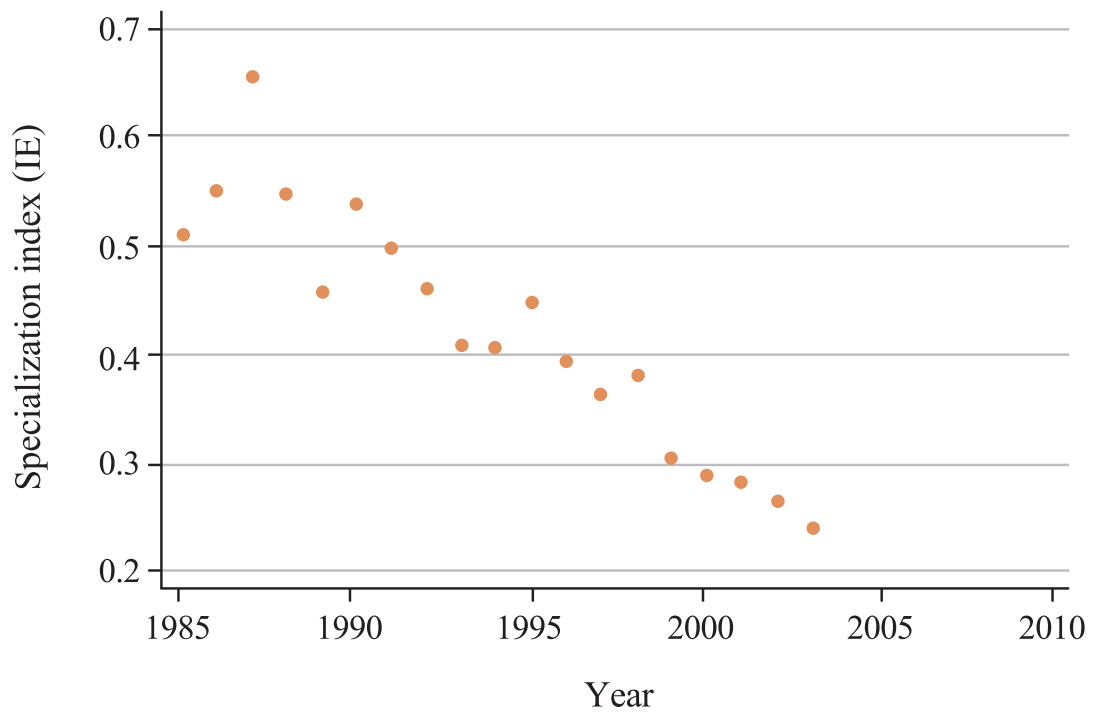



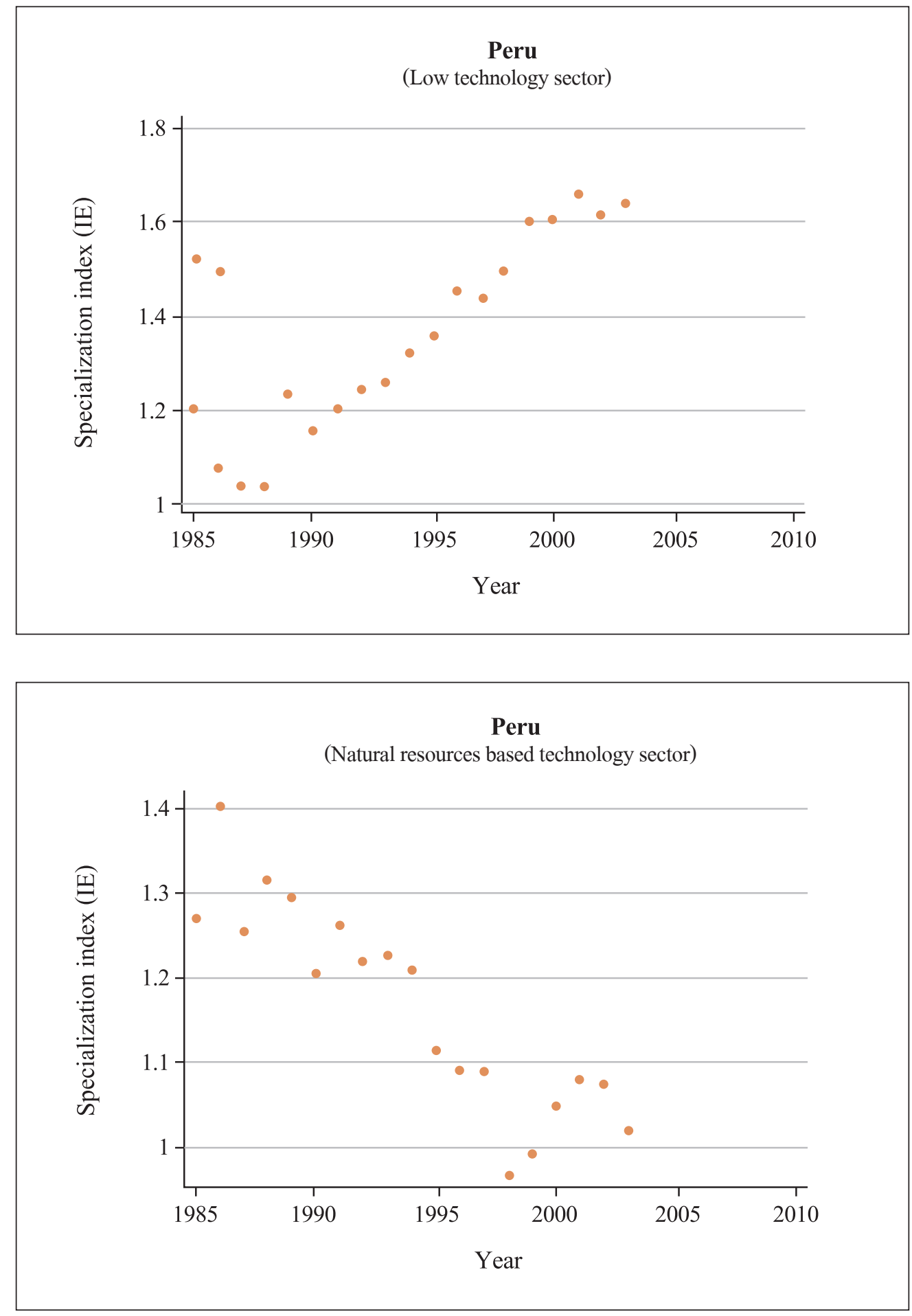

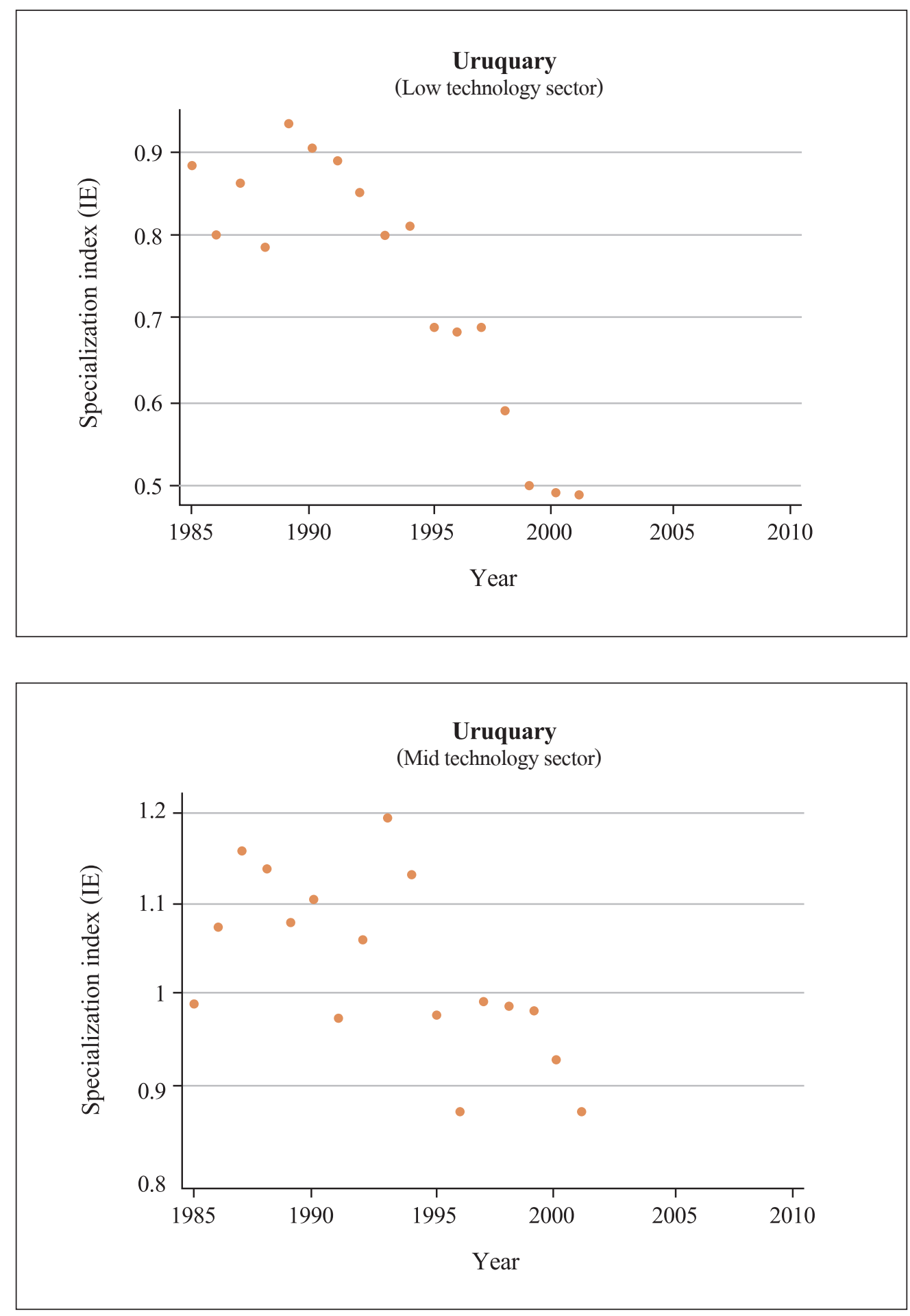

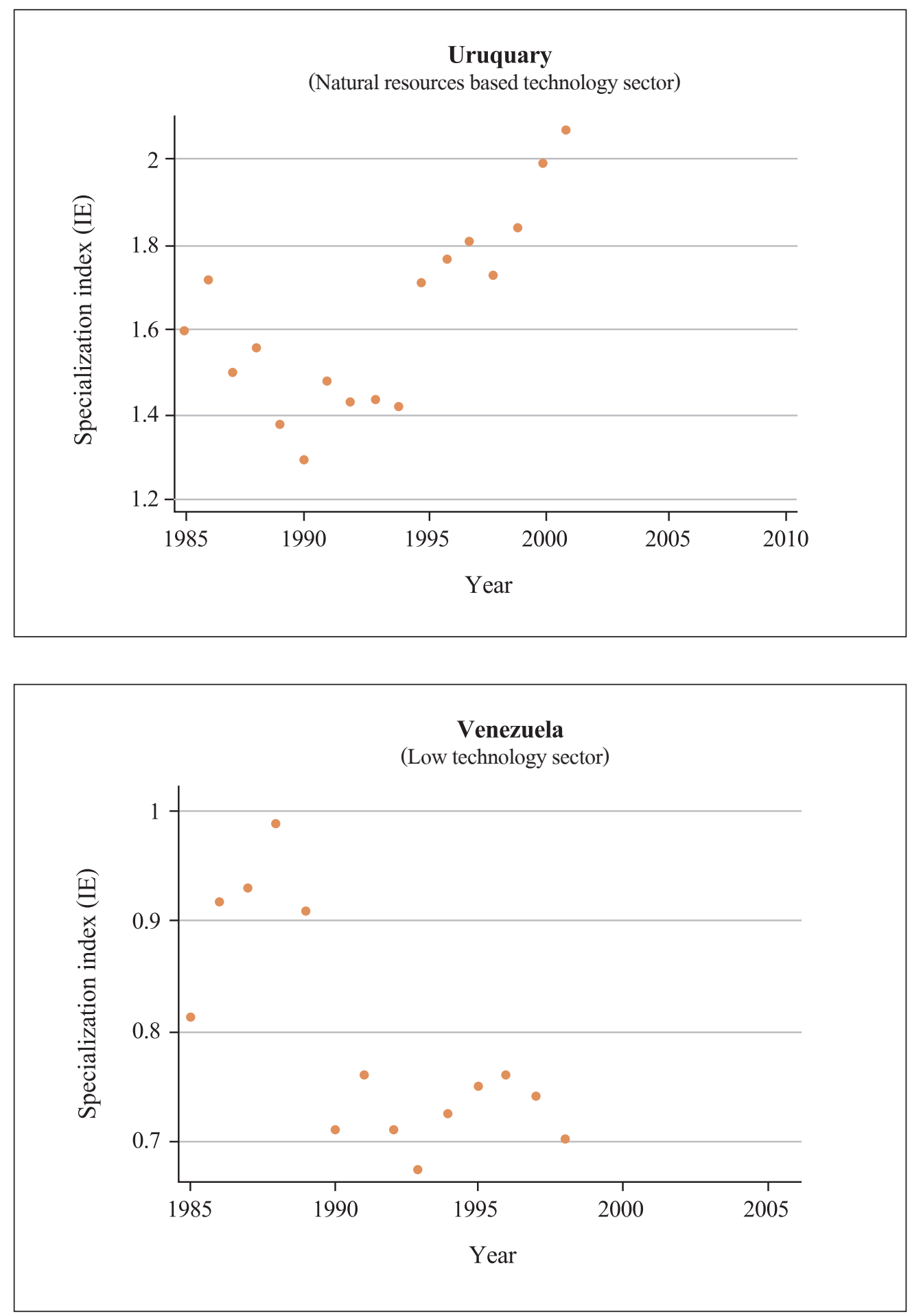


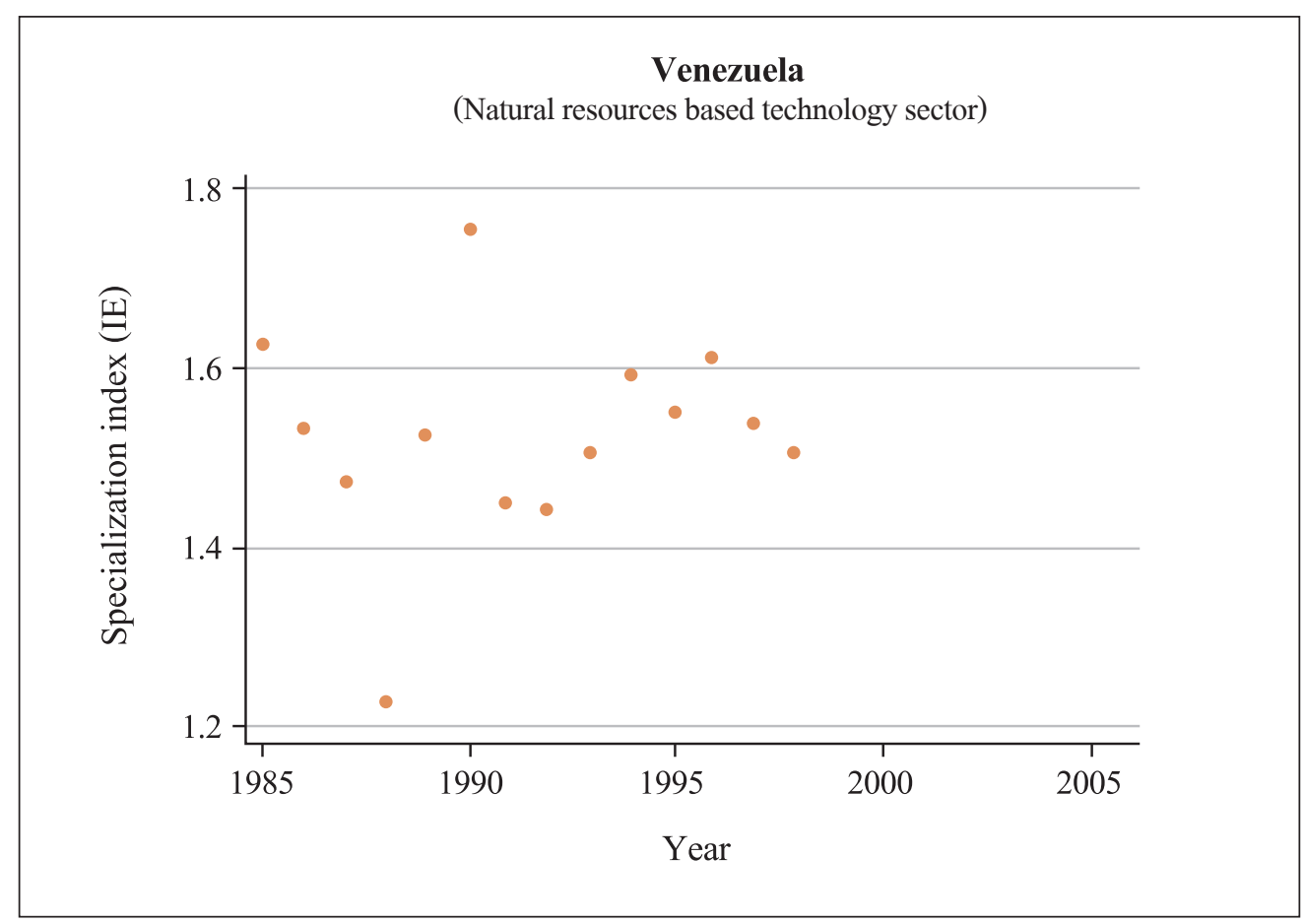


Figure A2. Revealed comparative advantage series, $V C R$
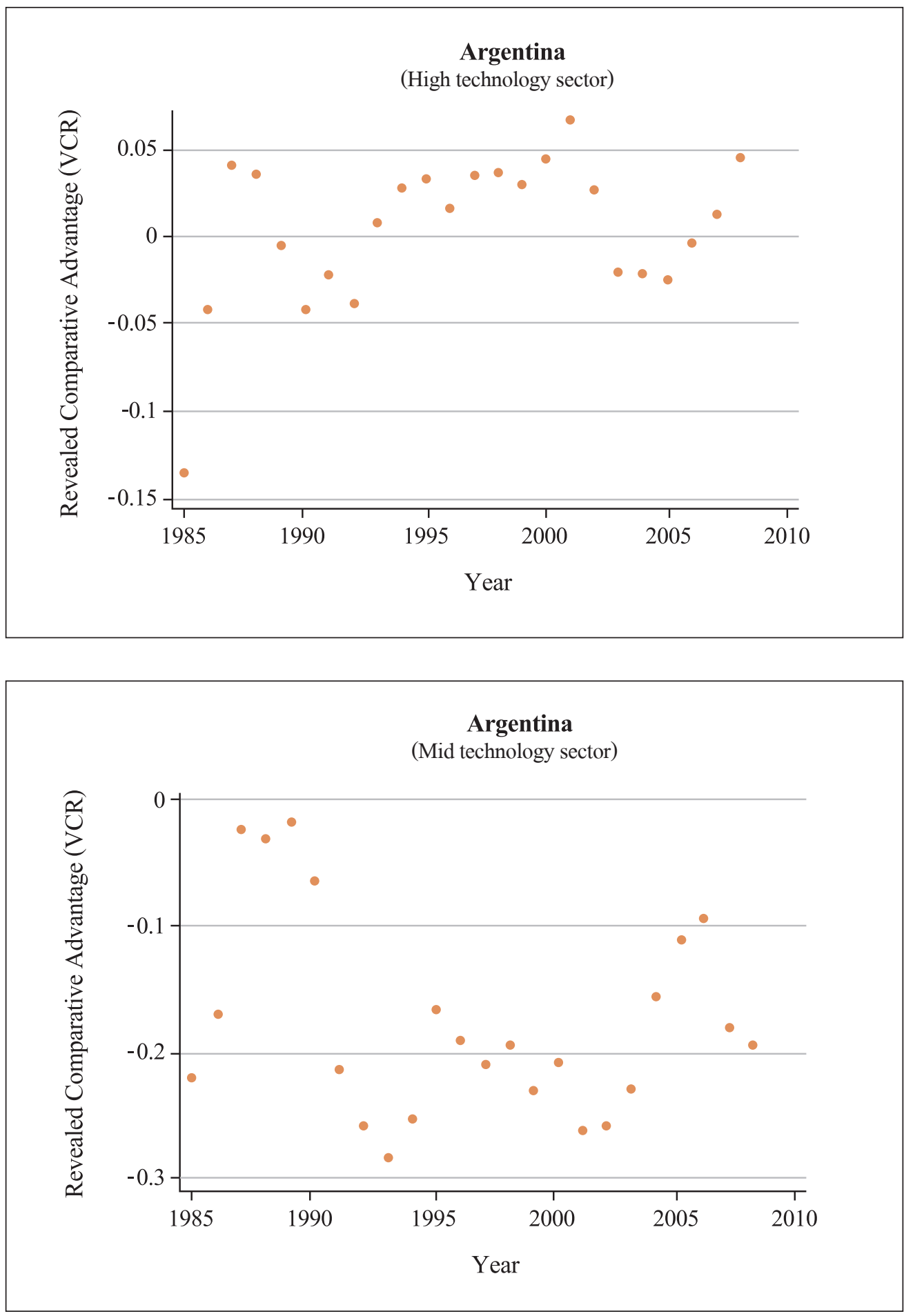

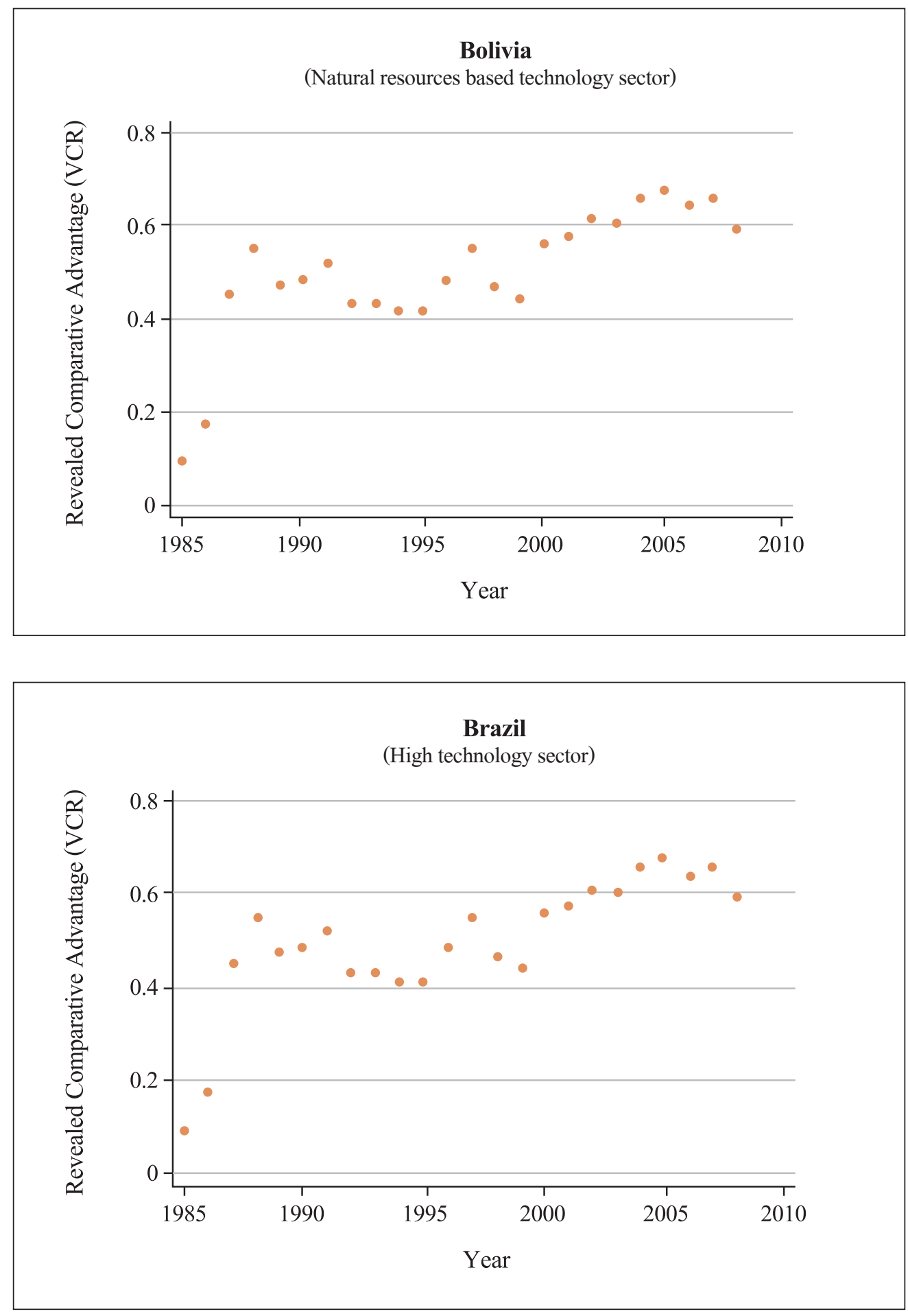


\section{Chile}

(High technology sector)

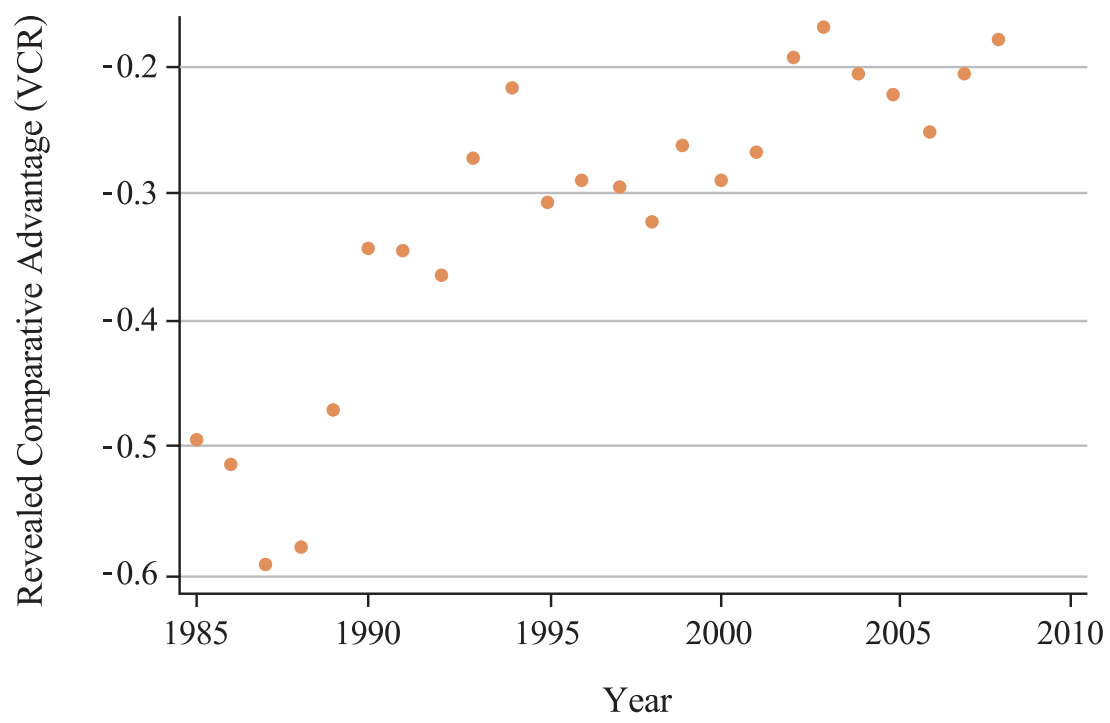

\section{Chile}

(Natural resources based technology sector)

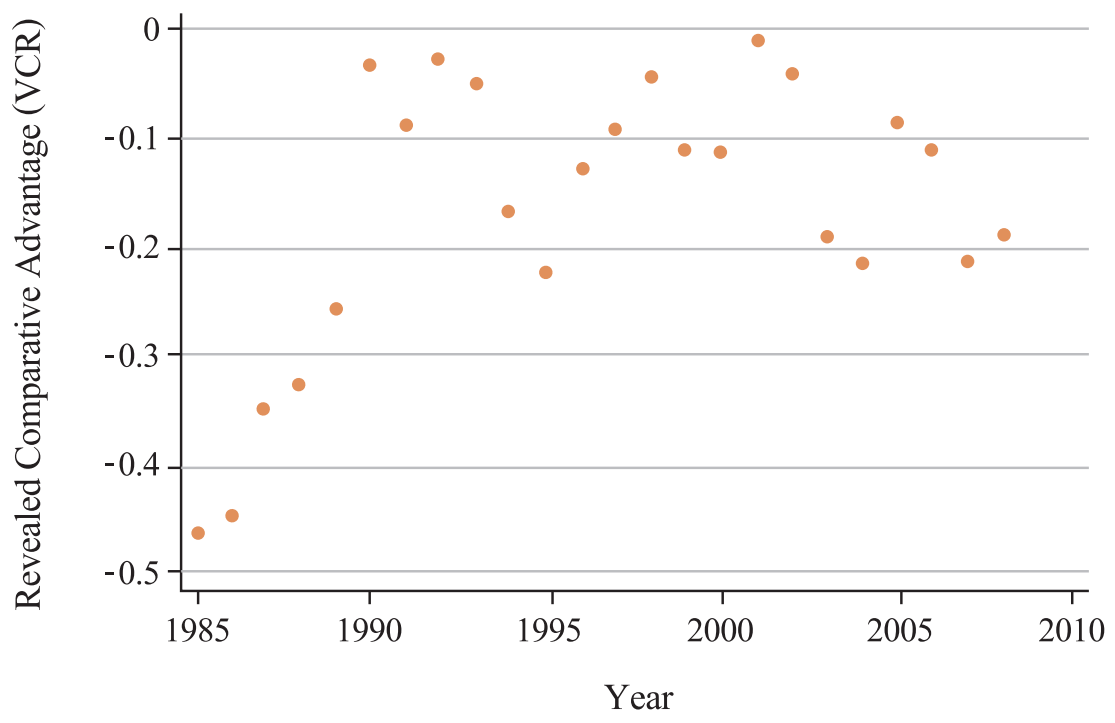



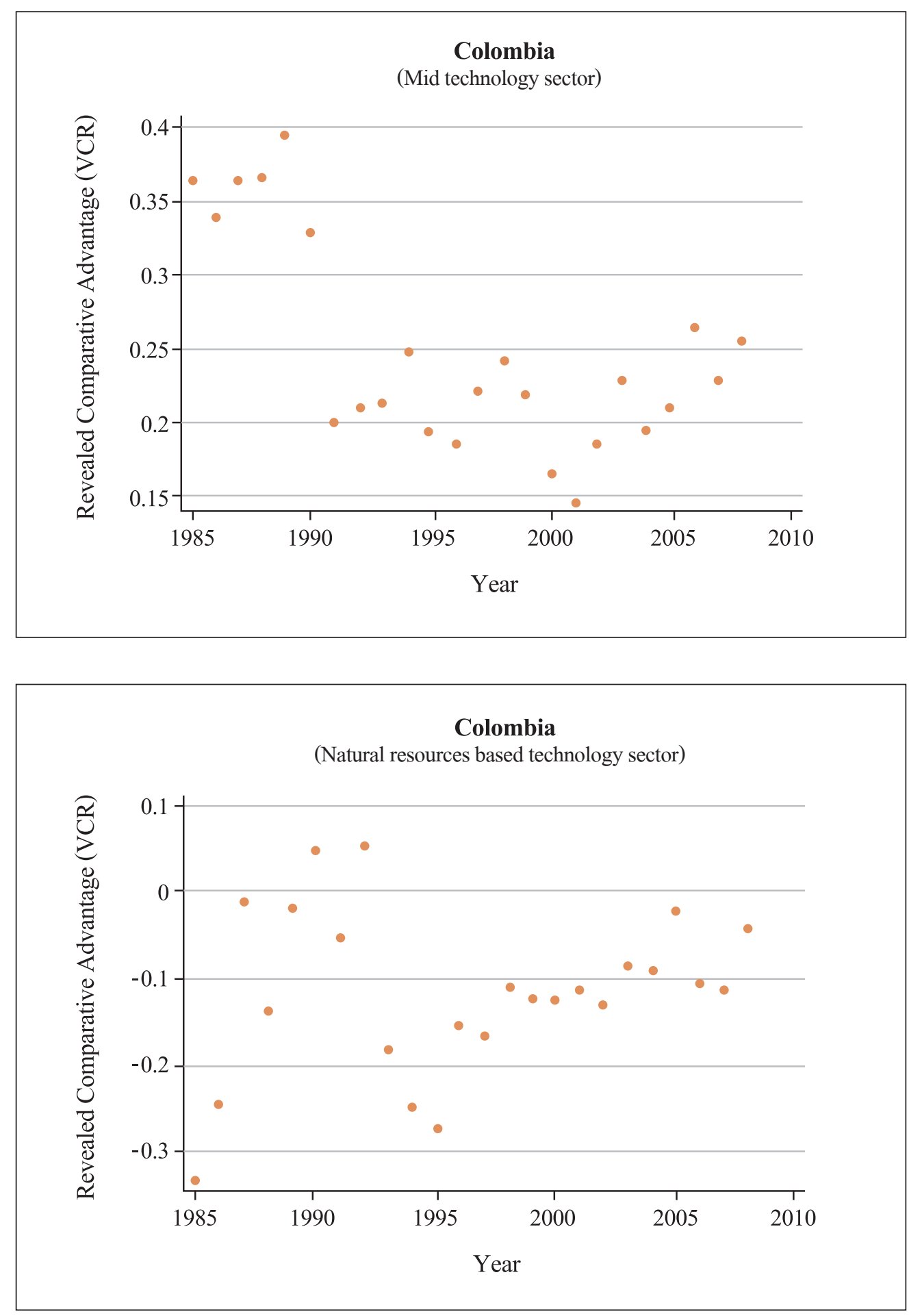

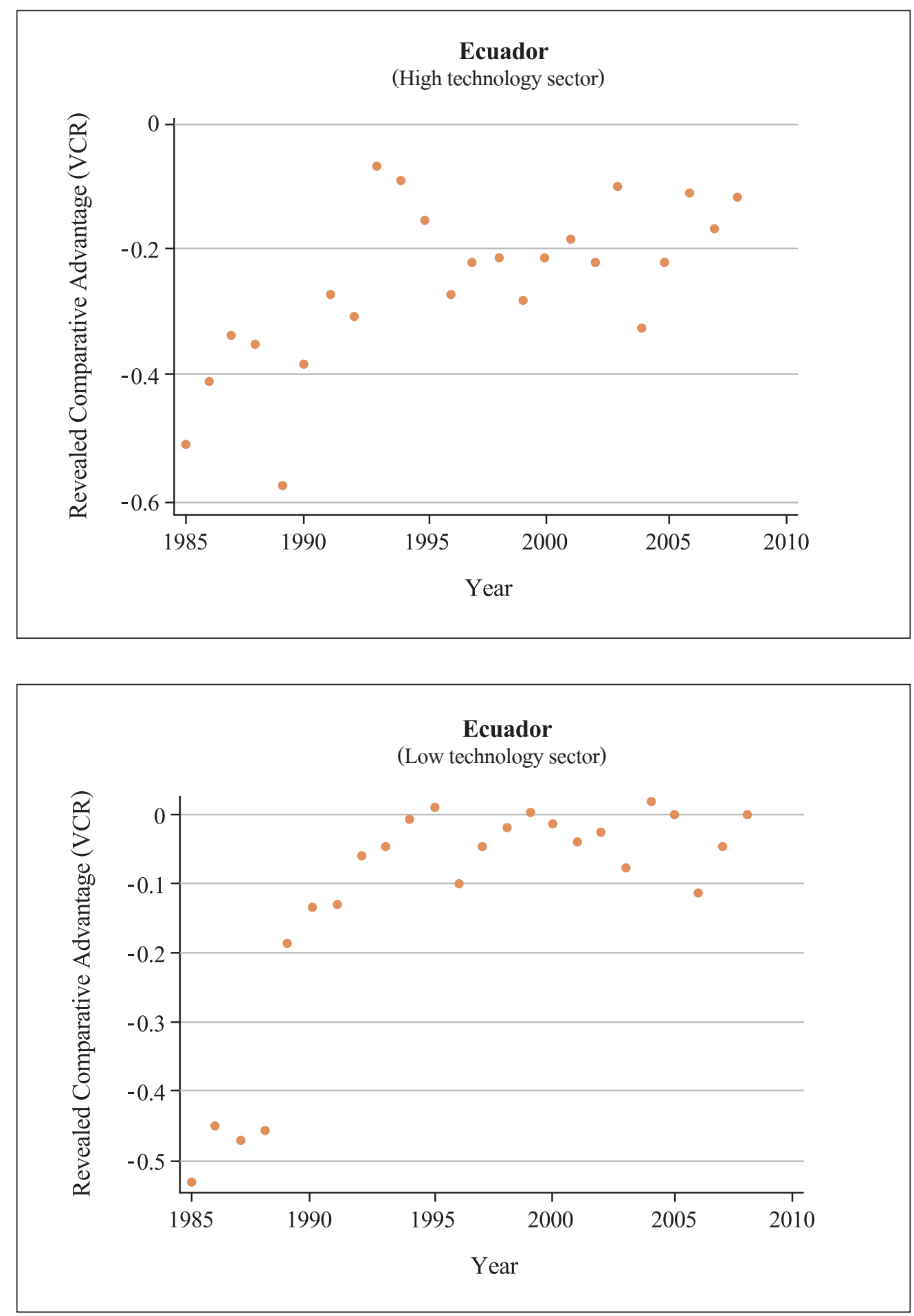

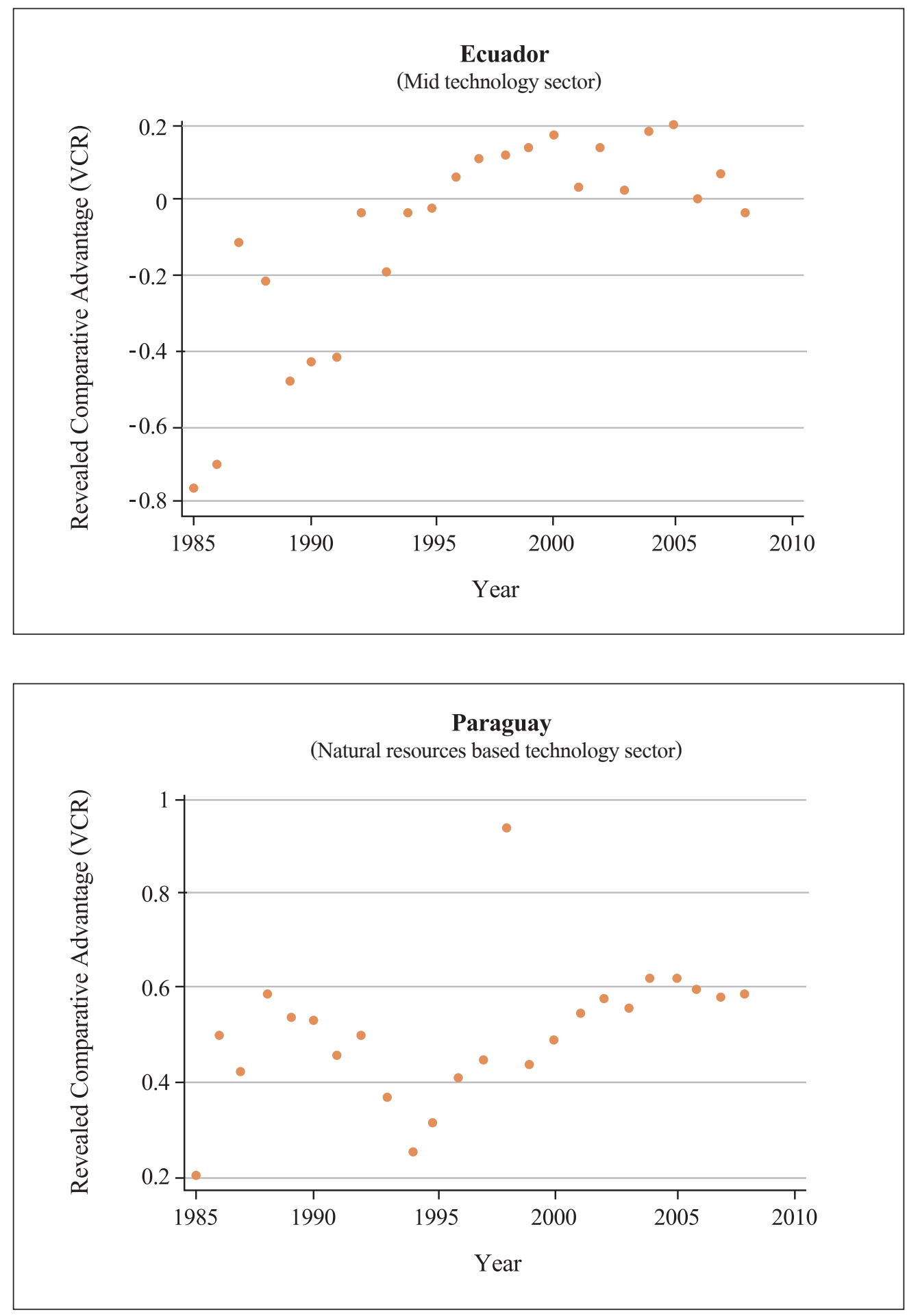

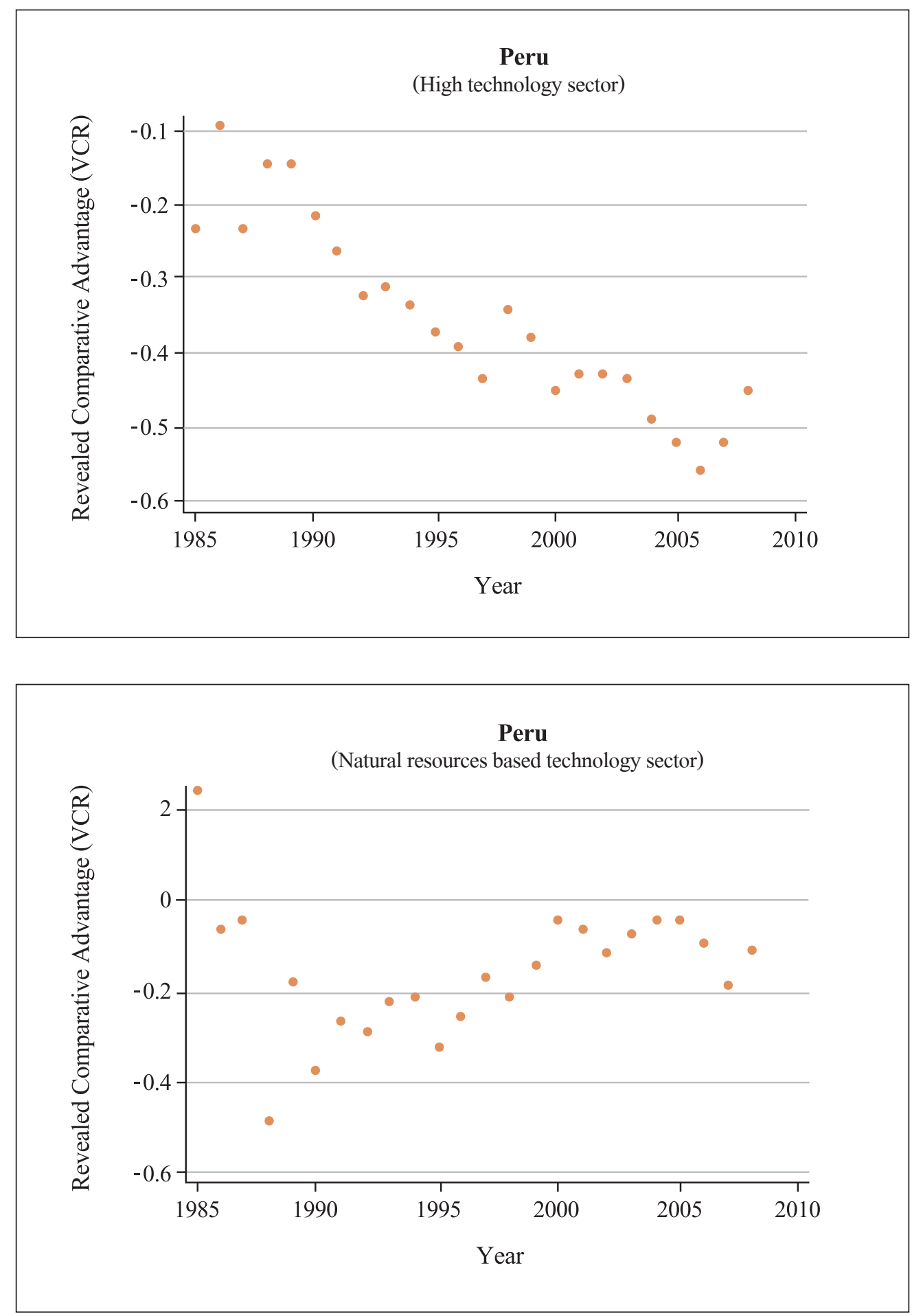

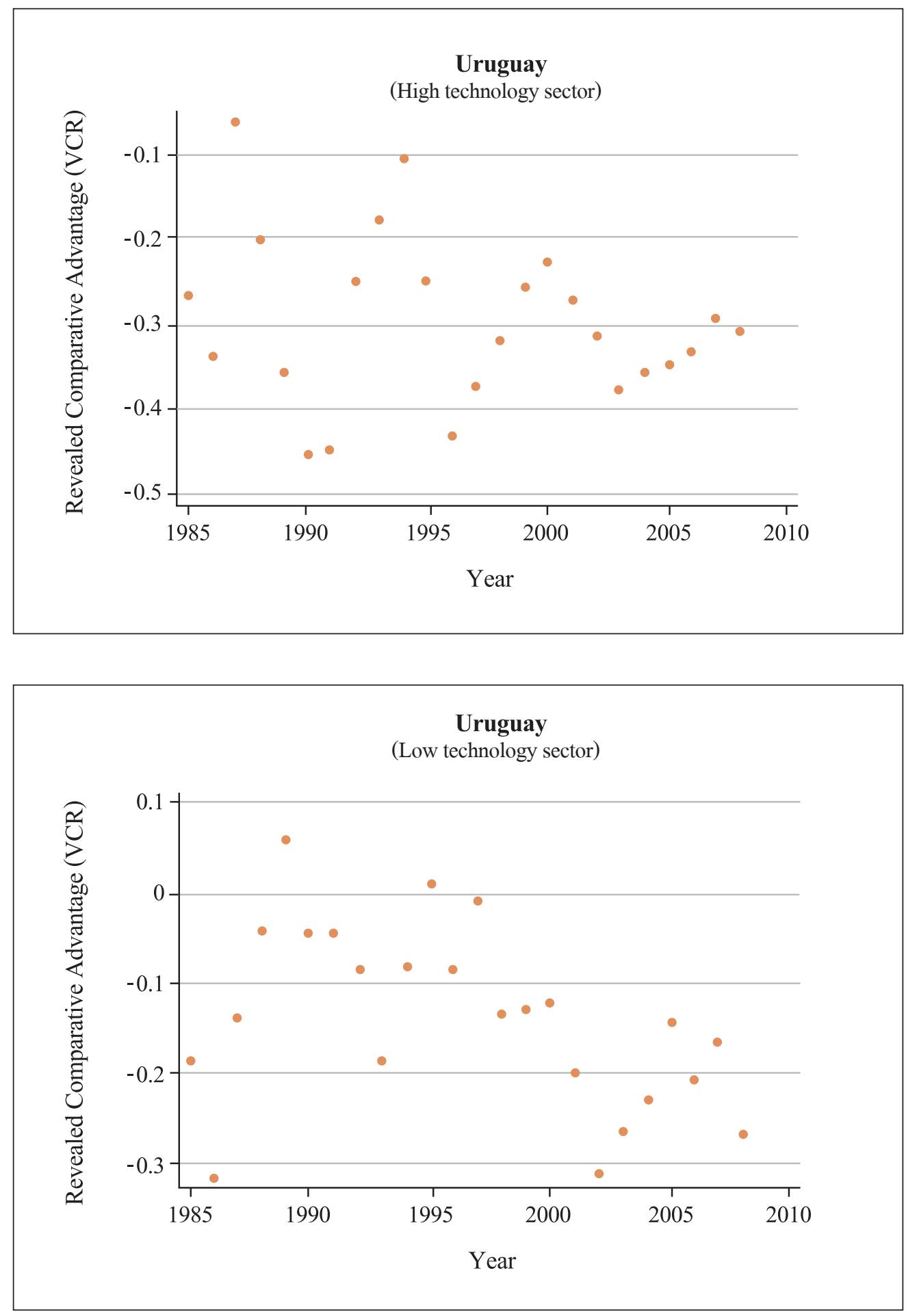
के

\begin{tabular}{|c|c|c|c|c|c|c|c|c|c|c|}
\hline .气̃ & 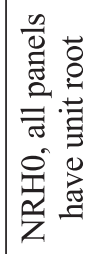 & 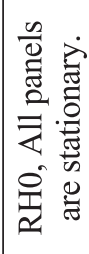 & 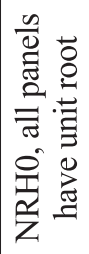 & 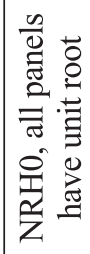 & 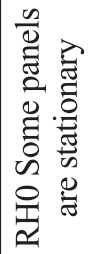 & 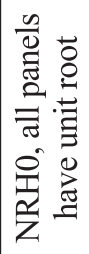 & 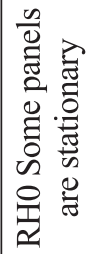 & 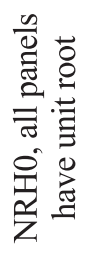 & 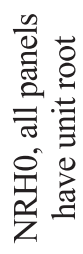 & 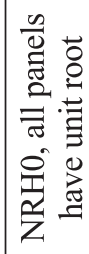 \\
\hline 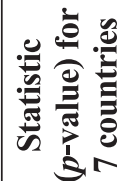 & 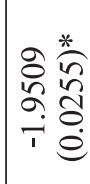 & $\begin{array}{l}\hat{2} \\
\hat{2} \\
\hat{1} 8 \\
i \\
1 \\
1\end{array}$ & 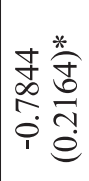 & 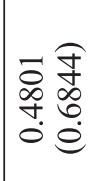 & $\begin{array}{l}\infty \\
2 \\
2 \\
n \\
n \\
1 \\
1\end{array}$ & 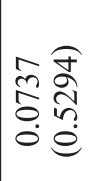 & 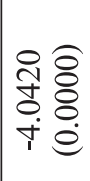 & 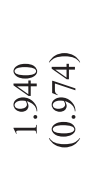 & 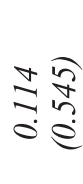 & 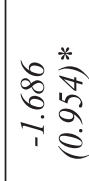 \\
\hline 苞 & 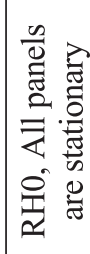 & 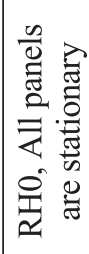 & 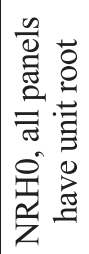 & 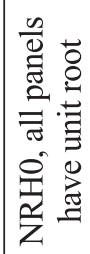 & 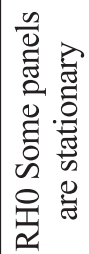 & 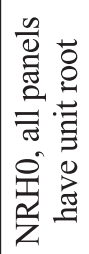 & 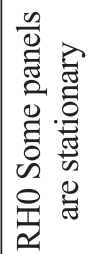 & 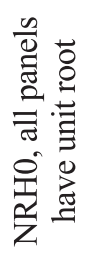 & 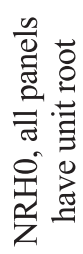 & 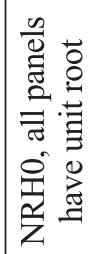 \\
\hline 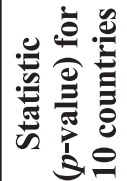 & $\mid \begin{array}{ll}* & \\
* & 8 \\
0 & 8 \\
0 & 0 \\
0 & 0 \\
1 & 0\end{array}$ & $\begin{array}{ll}* & \\
* & 0 \\
0 & 8 \\
0 & 8 \\
0 & 0 \\
0 & 0 \\
0 & 0\end{array}$ & 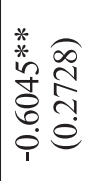 & 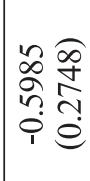 & 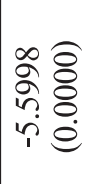 & 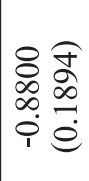 & 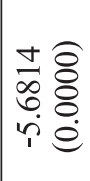 & $\begin{array}{l}\frac{0}{n} \\
\frac{n}{0} \\
\frac{1}{e}\end{array}$ & 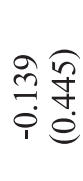 & 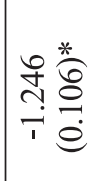 \\
\hline$\underline{ \pm}$ & 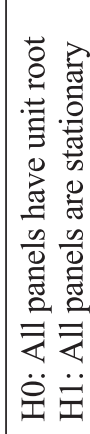 & 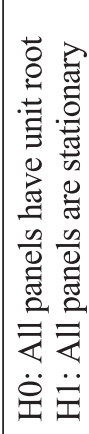 & 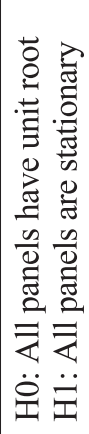 & 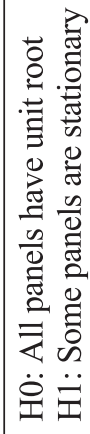 & 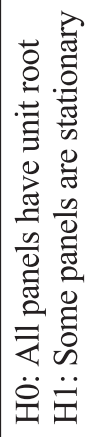 & 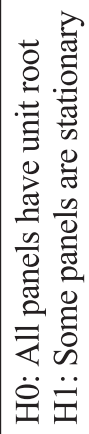 & 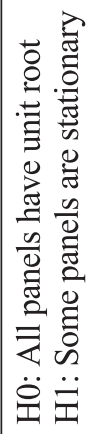 & 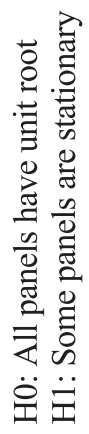 & 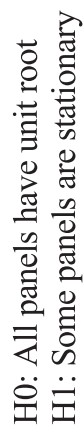 & 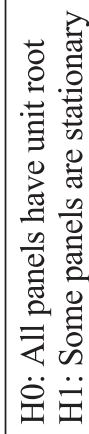 \\
\hline$\stackrel{\infty}{0}$ & 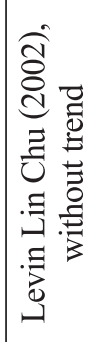 & 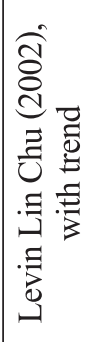 & 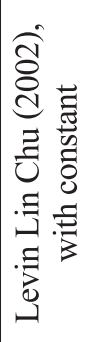 & 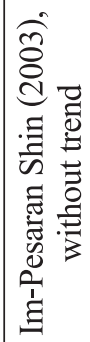 & 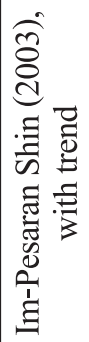 & 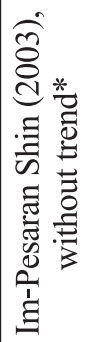 & 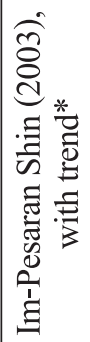 & 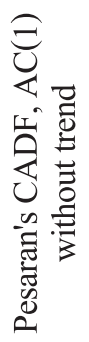 & 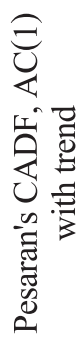 & 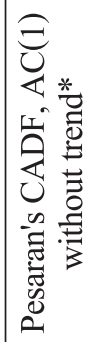 \\
\hline
\end{tabular}


త્త్ర

\begin{tabular}{|c|c|c|c|c|c|c|c|c|}
\hline .0 & 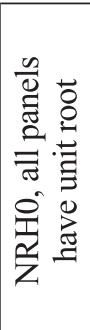 & 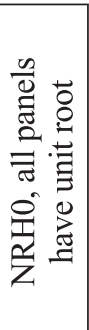 & 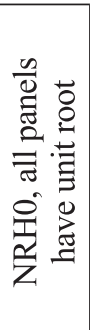 & 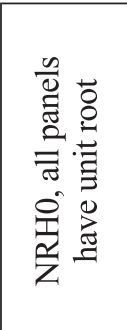 & 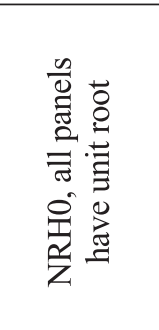 & 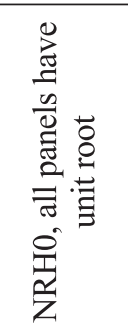 & 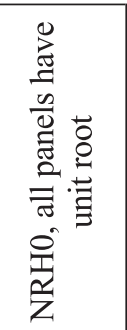 & \\
\hline 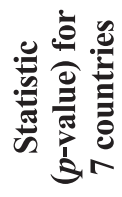 & $\mid \begin{array}{ll}n & 0 \\
0 & 0 \\
n & 1 \\
i & 1 \\
1 & e\end{array}$ & 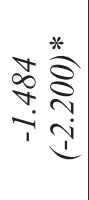 & 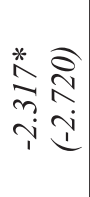 & 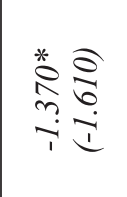 & 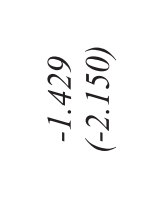 & 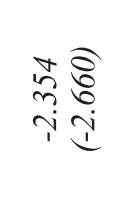 & 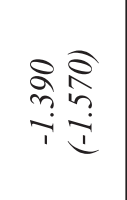 & \\
\hline 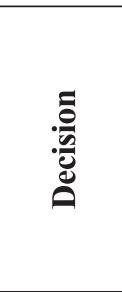 & 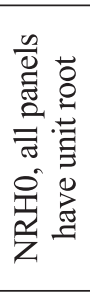 & 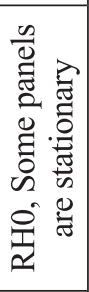 & 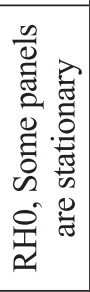 & 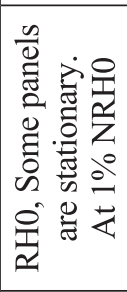 & 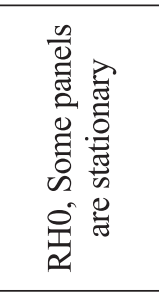 & 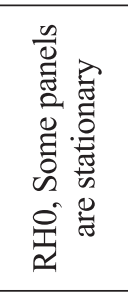 & 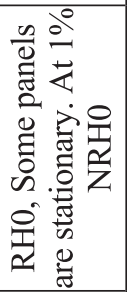 & 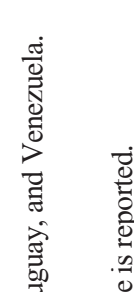 \\
\hline 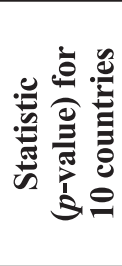 & $\mid \begin{array}{cc}\pi & 0 \\
\infty & \stackrel{9}{y} \\
0 & \stackrel{5}{0} \\
1 & 0\end{array}$ & 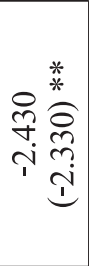 & 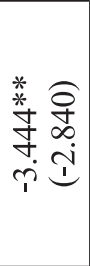 & 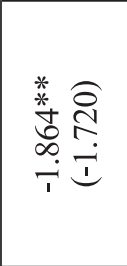 & 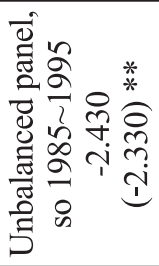 & 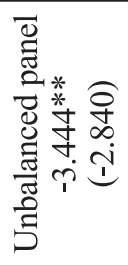 & 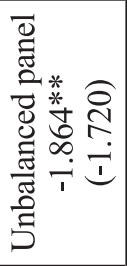 & 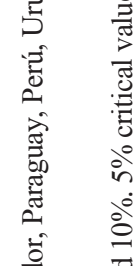 \\
\hline $\begin{array}{l}\underline{\Xi} \\
\hat{\theta}\end{array}$ & 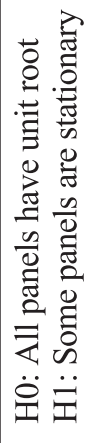 & 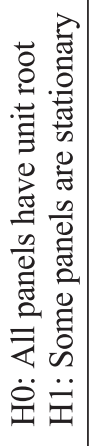 & 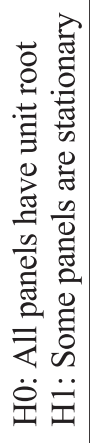 & 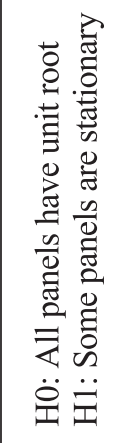 & 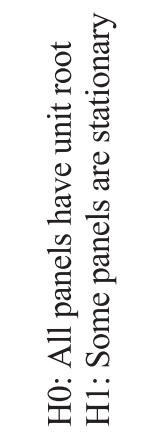 & 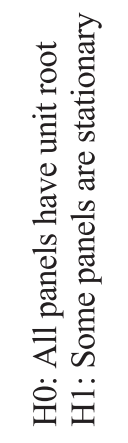 & 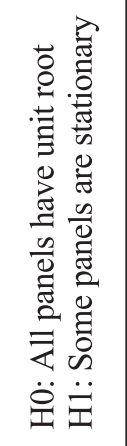 & 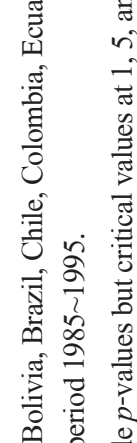 \\
\hline$\stackrel{s}{=}$ & 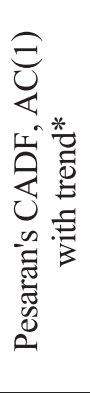 & 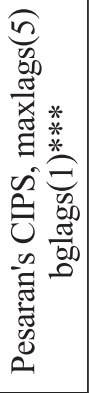 & 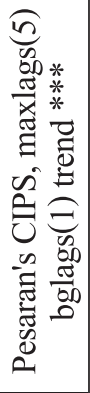 & 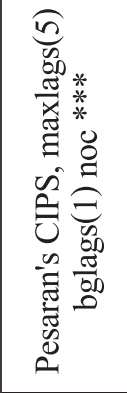 & 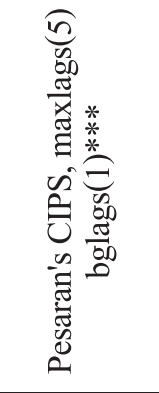 & 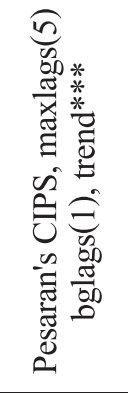 & 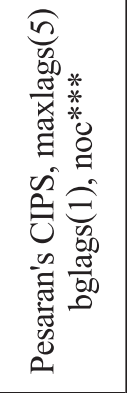 & 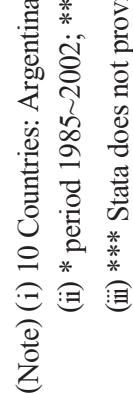 \\
\hline
\end{tabular}




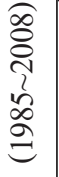

\begin{tabular}{|c|c|c|c|c|c|c|c|c|c|c|c|}
\hline 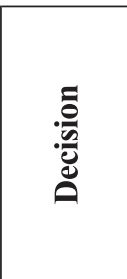 & 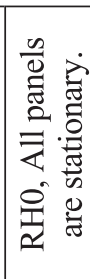 & 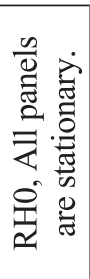 & 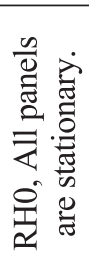 & 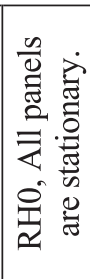 & 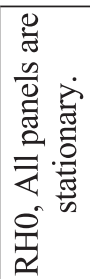 & 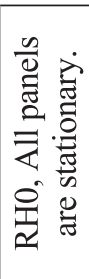 & 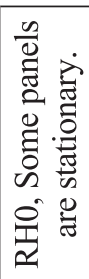 & 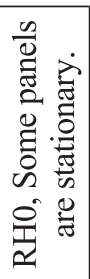 & 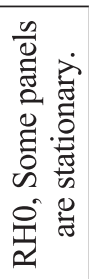 & 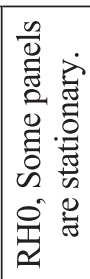 & 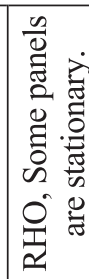 \\
\hline 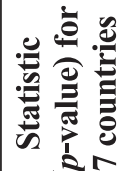 & 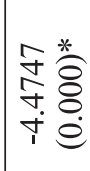 & 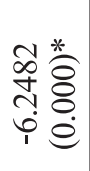 & 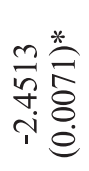 & 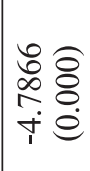 & 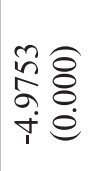 & 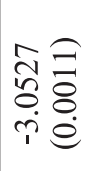 & 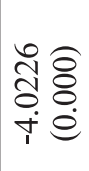 & 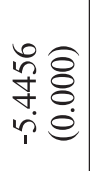 & 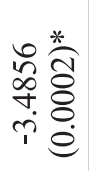 & 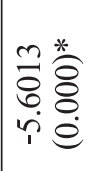 & $\frac{8}{6} \frac{\pi}{0}$ \\
\hline
\end{tabular}

\begin{tabular}{|c|c|c|c|c|c|c|c|c|c|c|c|}
\hline 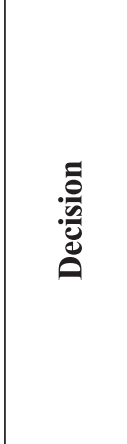 & 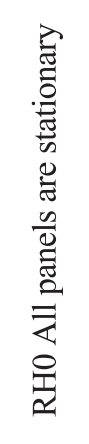 & 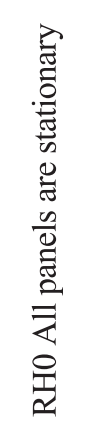 & 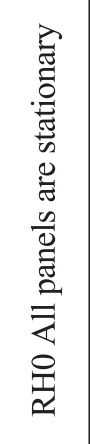 & 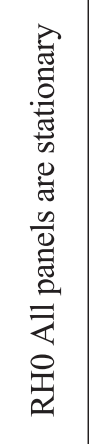 & 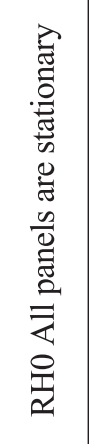 & 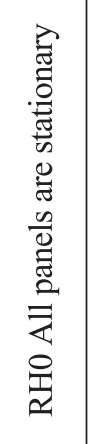 & 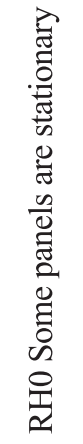 & 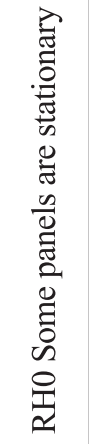 & 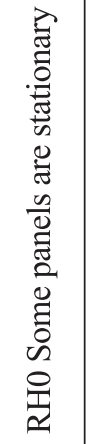 & 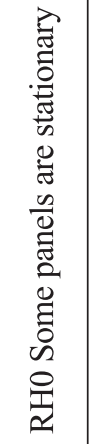 & 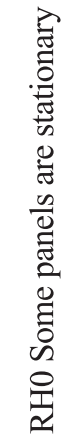 \\
\hline 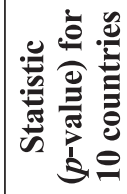 & $\begin{array}{l}\text { ठิ } \\
\text { †े } \\
+.8 \\
\text { r. }\end{array}$ & 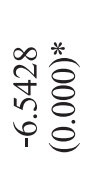 & 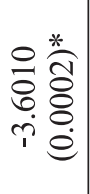 & 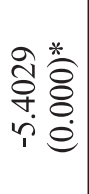 & 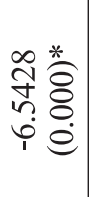 & 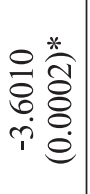 & 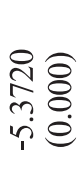 & 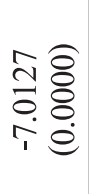 & $\begin{array}{cc}\infty & 0 \\
2 & 8 \\
\infty & 8 \\
+ & 0 \\
+ & 0\end{array}$ & 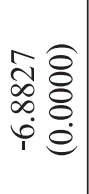 & 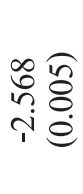 \\
\hline $\begin{array}{l}\underline{\underline{Z}} \\
\hat{\theta} \\
\underline{\underline{I}}\end{array}$ & 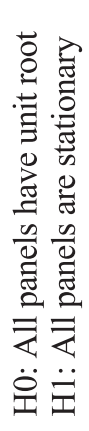 & 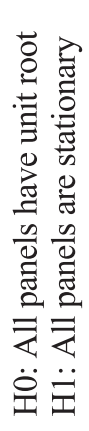 & 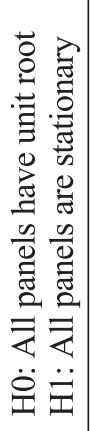 & 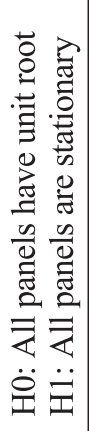 & 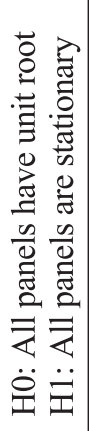 & 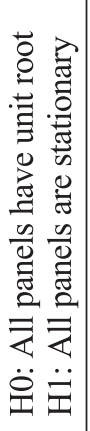 & 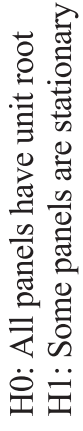 & 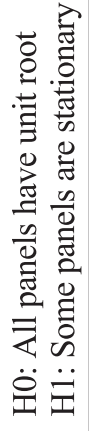 & 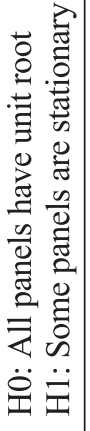 & 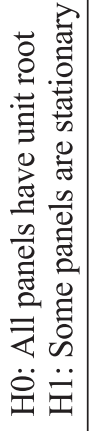 & 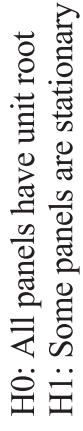 \\
\hline$\stackrel{5}{E}$ & 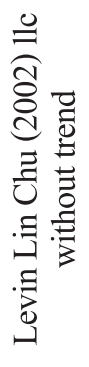 & 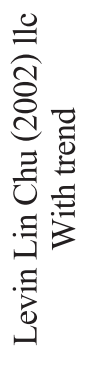 & 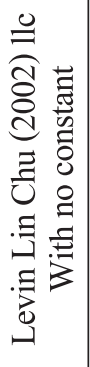 & 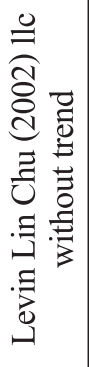 & 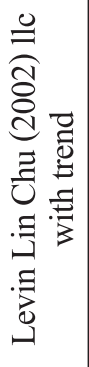 & 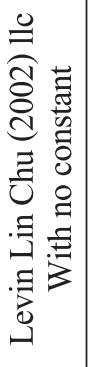 & 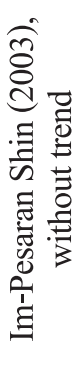 & 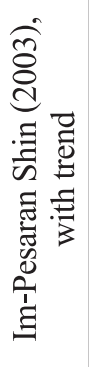 & 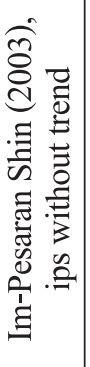 & 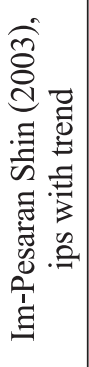 & 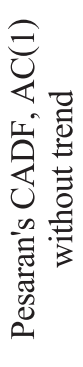 \\
\hline
\end{tabular}


氖

\begin{tabular}{|c|c|c|c|c|c|c|c|c|c|}
\hline .气 & 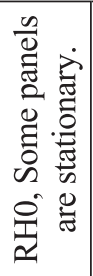 & 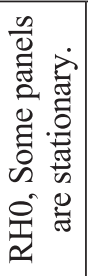 & 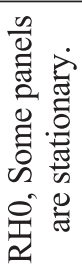 & 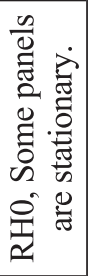 & 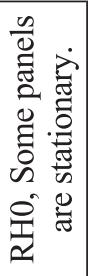 & 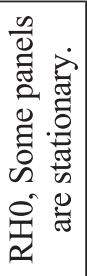 & 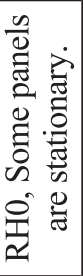 & 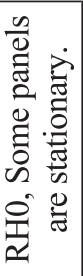 & 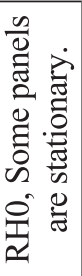 \\
\hline م & $\begin{array}{ll}n & \hat{\sigma} \\
0 & 8 \\
+ & 0 \\
i & 0\end{array}$ & 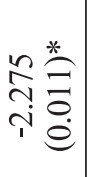 & 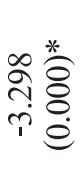 & 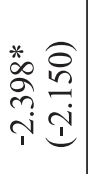 & 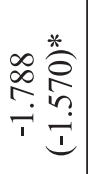 & 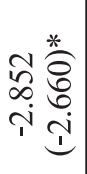 & 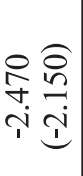 & 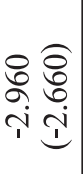 & 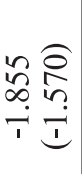 \\
\hline . & 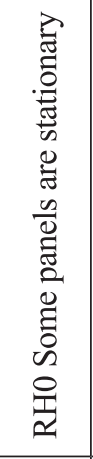 & 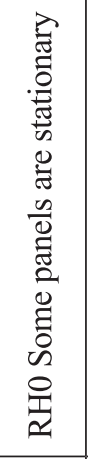 & $\begin{array}{l}\text { 콜 } \\
0 \\
0 \\
0 \\
0 \\
0 \\
0 \\
0 \\
0 \\
0 \\
0 \\
0 \\
0 \\
0 \\
0 \\
0 \\
0 \\
0 \\
0 \\
0 \\
0\end{array}$ & 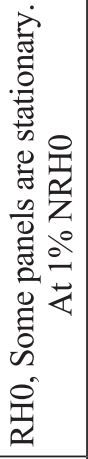 & 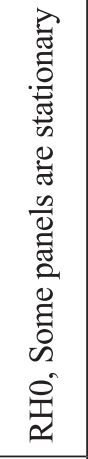 & 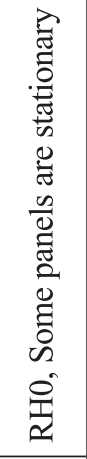 & 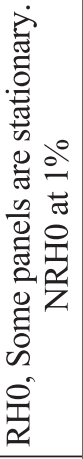 & 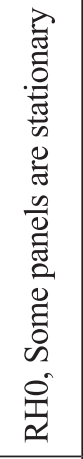 & 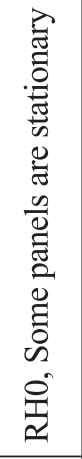 \\
\hline 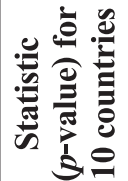 & $\begin{array}{ll}\hat{n} & \overline{8} \\
\hat{\sigma} & 0 \\
\hat{r} & 0\end{array}$ & 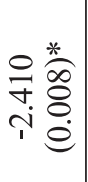 & 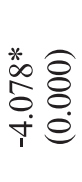 & 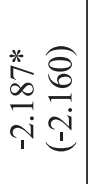 & 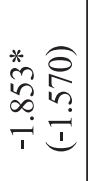 & 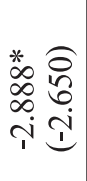 & 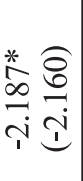 & 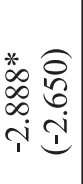 & $\begin{array}{l}* \\
\cdots \\
n \\
\infty \\
\infty \\
i \\
i\end{array}$ \\
\hline & 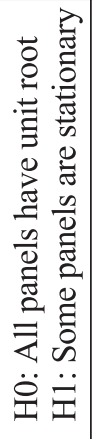 & 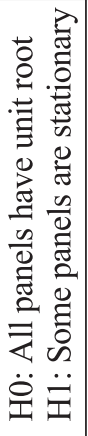 & 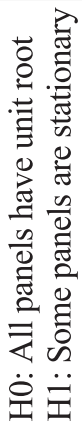 & 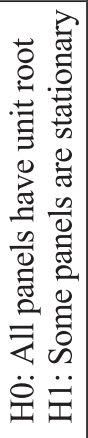 & 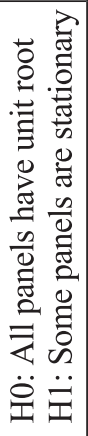 & 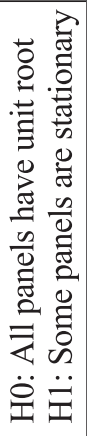 & 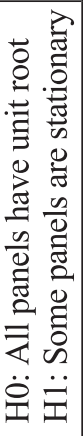 & 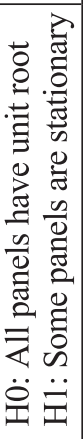 & 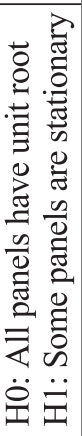 \\
\hline $\mathscr{\sigma}$ & 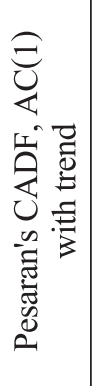 & 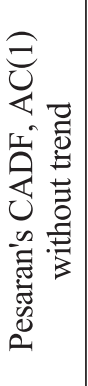 & 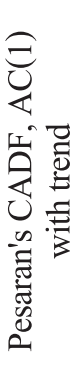 & 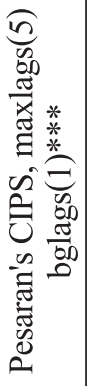 & 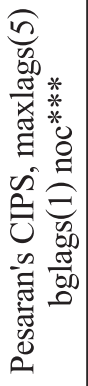 & 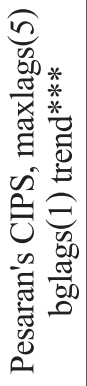 & 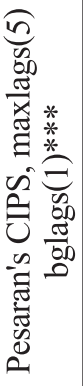 & 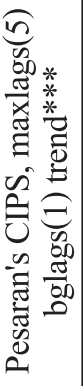 & 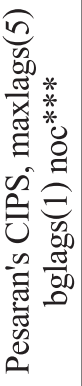 \\
\hline
\end{tabular}

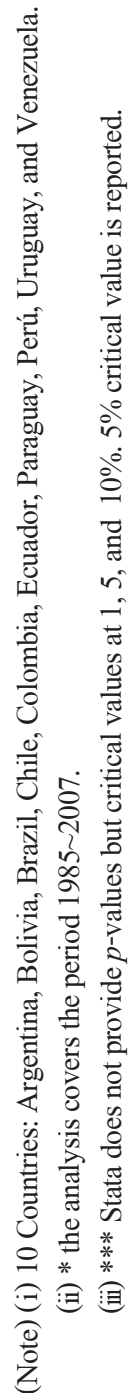

